\title{
Tackling probiotic and gut microbiota functionality through proteomics
}

\author{
Lorena Ruiz $^{\mathrm{a}}$, Claudio Hidalgo ${ }^{\mathrm{b}}$, Aitor Blanco-Míguez ${ }^{\mathrm{c}}$, Anália Lourenço ${ }^{\mathrm{c}, \mathrm{d}}$, \\ Borja Sánchez ${ }^{\mathrm{b}, *}$, Abelardo Margolles ${ }^{\mathrm{b}}$ \\ a Department of Nutrition, Food Science and Technology, Complutense University of Madrid, Avda. Puerta de Hierro s/n, 28040 Madrid, Spain

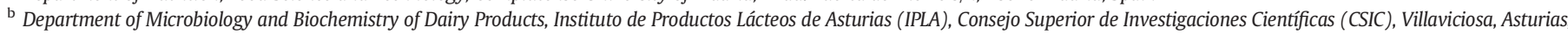 \\ Spain \\ c ESEI - Department of Computer Science, University of Vigo, Edificio Politécnico, Campus Universitario As Lagoas s/n, 32004, Ourense, Spain \\ d CEB - Centre of Biological Engineering, University of Minho, Campus de Gualtar, 4710-057 Braga, Portugal
}

\section{A R T I C L E I N F O}

\section{Article history:}

Received 15 January 2016

Received in revised form 19 February 2016

Accepted 10 March 2016

Available online 18 March 2016

\section{Keywords:}

Probiotics

Gut microbiota

Stress adaptation

Proteomics

Metaproteomics

\begin{abstract}
A B S T R A C T
Probiotics are live microorganisms which when administered in adequate amounts confer a health benefit on the host. Many strains exert their beneficial effects after transiently colonizing the human gut, where they interact with the rest of the intestinal microorganisms and with the host mucosa. Indeed the human gut harbours a huge number of microorganisms also known as gut microbiota. Imbalances in the relative abundances of the individual components of the gut microbiota may determine the health status of the host and alterations in specific groups have been related to different diseases and metabolic disorders.

Proteomics provide a set of high-throughput methodologies for protein identification that are extremely useful for studying probiotic functionality and helping in the assessment of specific health-promoting activities, such as their immunomodulatory activity, the intestinal colonization processes, and the crosstalk mechanisms with the host. Furthermore, proteomics have been used to identify markers of technological performance and stress adaptation, which helps to predict traits such as behaviour into food matrices and ability to survive passage through the gastrointestinal tract. The aim of this review is to compile studies in which proteomics have been used to assess probiotic functionality and to identify molecular players supporting their mechanisms of action. Significance: Probiotics are live microorganisms which when administered in adequate amounts confer a health benefit on the host. Molecular basis underlying the functional properties of probiotic bacteria responsible for the health promoting effects have been in the background for many years. Breakthrough of omics technologies in the probiotic and microbiota fields has had a very relevant impact in the elucidation of probiotic mechanisms and in the procedures to select these microorganisms, based on solid scientific evidence. It is unquestionable that, in the near future, the evolution of proteomic techniques will play a pivotal role in the generation of knowledge about the functions of probiotics and gut commensals, still a pending issue in the field of intestinal microbiomics.
\end{abstract}

(c) 2016 Elsevier B.V. All rights reserved.

\section{Contents}

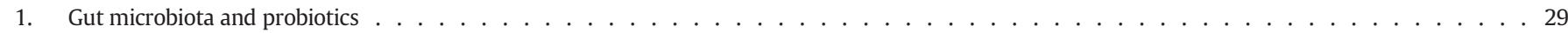

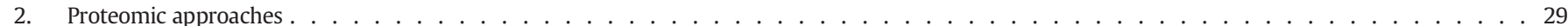

2.1. Gel-based proteomics. . . . . . . . . . . . . . . . . . . . . . . . . . 30

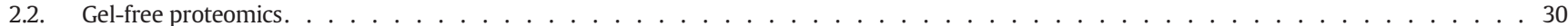

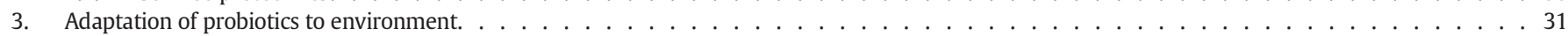

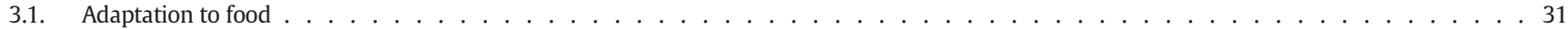

3.2. Adaptation to the intestinal environment . . . . . . . . . . . . . . . . . . . . . . . . . .

4. Proteomics for the study of changes in probiotic functionality . . . . . . . . . . . . . . . . . . . . . . . . . . . 34

5. Proteomics of simple and complex microbial populations: metaproteomics . . . . . . . . . . . . . . . . . . . . . . . . . . . 34

6. Proteomics of sub-cellular fractions . . . . . . . . . . . . . . . . . . . . . . . . . . . . 34

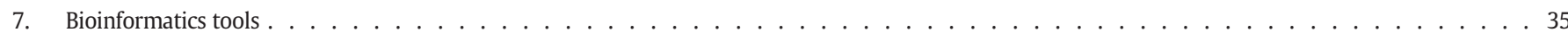

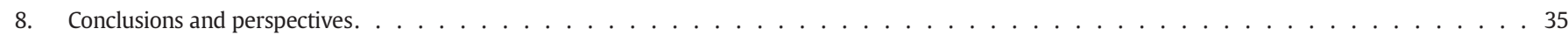

\footnotetext{
* Corresponding author.

E-mail address: borja.sanchez@csic.es (B. Sánchez).
} 
Conflict of interest . . . . . . . . . . . . . . . . . . . . . . . . . . . . . . . . . . . . . 36

Acknowledgements . . . . . . . . . . . . . . . . . . . . . . . . . . . . . . . . . . . . . . . . 36

References... . . . . . . . . . . . . . . . . . . . . . . . . . . . . . . . . . . . . . 36

\section{Gut microbiota and probiotics}

Since the beginning of the 20th century we have scientific evidence that there are beneficial microbes consumed in food that exert healthy effects. Already in 1907, Elie Metchnikoff, the Nobel Prize in Physiology or Medicine in 1908, published a book with the title "The Prolongation of Life: Optimistic Studies". In this book he mentioned some observations related to the consumption of bacteria responsible for dairy fermentation, and he highlighted the association between the consumption of fermented dairy products in some Eastern European areas and an unusually large number of centenarians [1]. Later on, fermented milks including specific lactic acid bacteria strains selected for specific health purposes started to be commercialized [2] and during the 50 's the first therapies using probiotics were published in renowned medical journals [3].

Probiotics are traditionally associated with fermented foods, being lactobacilli and bifidobacteria the two main bacterial groups used by the food industry. During the last decades, probiotics have been defined in many different ways [4], but the first broad consensus definition was coined by a joint Expert Consultation Scientific Committee working on behalf of the FAO and the WHO [5]. The scientific panel defined probiotics as "live microorganisms which when administered in adequate amounts confer a health benefit on the host" (this definition was recently revised by the International Scientific Association of Probiotics and Prebiotics; [6]. In the FAO/WHO document, some in vitro tests to screen potential probiotic microorganisms were recommended, including adherence to mucus and/or human epithelial cells and cell lines, antimicrobial activity against potential pathogens, ability to reduce pathogen adhesion or displaying bile salt hydrolase activity. These screening tests became the dogma for probiotic characterization, but this phenotypic characterization does not allow going deeply into the mechanisms underlying the functionality of probiotics, a key issue to generate solid evidence-based science to support the observed beneficial effects attributed to these bacteria. Mechanistic studies have also been hampered by the lack of genetic tools to genetically modify lactobacilli and bifidobacteria; in the particular case of bifidobacteria gene silencing or protein production has been achieved only for a few model strains [7].

Maybe the key feature of probiotic microorganisms, in addition to their health promoting effects, is their ability to modulate the human microbiota. In most of the studies, this term relates to the microbial community inhabiting the human gastrointestinal tract (GIT), although a probiotic can target the microbiota from other body locations, mainly mucosae. In the case of our gut, about $10^{14}$ microorganisms endow us with relevant metabolic and functional attributes with their pool of genomes, also known as microbiome [8]. Currently, it is estimated that 10 million unique genes compose the human gut microbiome [9] (http:// gigadb.org/dataset/100064).

The gut microbiota exerts a fundamental role in human health by promoting intestinal homeostasis, stimulating development of the immune system, providing protection against pathogens, and contributing to the production of micronutrients and energy [10]. Therefore, it can be easily deduced that microbiota plays a pivotal role in human health, notably at the level of the relative compositions of their single microbial species [11]. Indeed modifications in its composition have been related to a number of metabolic disorders and diseases, notably with an autoimmune or chronic inflammatory component, including inflammatory bowel diseases, systemic lupus erythematosus (SLE), metabolic syndrome, rheumatoid arthritis, type- 1 diabetes, and obesity [12-17]. Currently, the interaction between intestinal microbiota and different organs, such as gut-liver axis and gut-brain axis, is becoming evident; thus dysbiosis in this microbial community has been associated with liver disease, mood, autism or brain development disturbances [18].

Microbiota increases in number, density and complexity from the oral cavity to the colon [19], and it contains microorganisms belonging to the three domains of life: Eucarya, Bacteria and Archea. Bacteroidetes and Firmicutes are the dominant bacterial phyla in adults, whereas the main archaea identified to date is the methanogenic Methanobrevibacter smithii $[9,20]$. Almost all bacteria members can be ascribed to nine phyla, with Bacteroides and Firmicutes accounting from almost $90 \%$ of these populations; other phyla such as Actinobacteria - in which bifidobacteria are is included - constitute subdominant groups [9,21].

In this populated scenario, orally ingested probiotics must deal with stressful conditions characterizing the human GIT (acidic pH, bile and digestive enzymes), starving conditions and microbial antagonism interrelationships. The advent of omics techniques during the last decade has allowed overtaking many of the inconveniences associated with the molecular characterization of probiotic functionality, and proteomics plays a pivotal role in this process. Using different proteomic methods, mainly, but not exclusively, gel-based approaches, scientists have been able to identify the molecular players involved in different stress responses critical for survival during industrial processing [22] and/or along the gastrointestinal tract transit [23,24], and to know the proteins involved in important metabolic functions, such as mucin utilization [25], as well as in adhesion, immune stimulation and other hostmicrobial interactions [26,27].

\section{Proteomic approaches}

In microbiology, the classical definition of proteome can be adapted to "the complete protein complement of a cell or subcellular fraction of a microorganism in a defined growth phase under concrete and precise physiological conditions" [28]. During the last decades a huge amount of genetic information has been obtained thanks to the development of genomics (mainly DNA sequencing technologies and platforms) and Bioinformatics (algorithms, massive data storage and query and data integration). However genomics is not enough to explain the complex biological events that are mediated by proteins, as the presence of a simple gene says very few about its expression and the production of a bioactive protein. Therefore, in the omics era, proteomics has become more interesting since they allow detecting proteins involved in the main cellular functions such as catalysis and stress responses. The proteomic approaches involve all the techniques used to identify and quantify the complete set of proteins present in a sample, cell or tissue under defined experimental conditions. A detailed review of common techniques was written by Monteoliva and Albar [29] and further reviewed by Abdallah and co-workers [30]. Further reviews for the application of proteomics to the study of probiota/microbiota functionality are also available in the scientific literature [31,32]. Setting a proteomics experiment involves all parameters affecting sample preparation (basically protein extraction and purification), followed by gel-based/gel-free protein separation coupled to a mass spectrometer step in which the polypeptides/proteins are finally detected through their mass-to-charge ratio (Fig. 1). The most common approach is the so-called "Bottom-up proteomics", in which proteins are digested (usually through the action of trypsin) and the resulting mix of peptides detected in the mass spectrometer. This contrasts with the "Top-down" proteomics, in which proteins are not digested prior separation, and which is very useful for the detection of protein degradation products, isoforms, posttranslational modifications or truncated proteins [33]. In the identification step, 

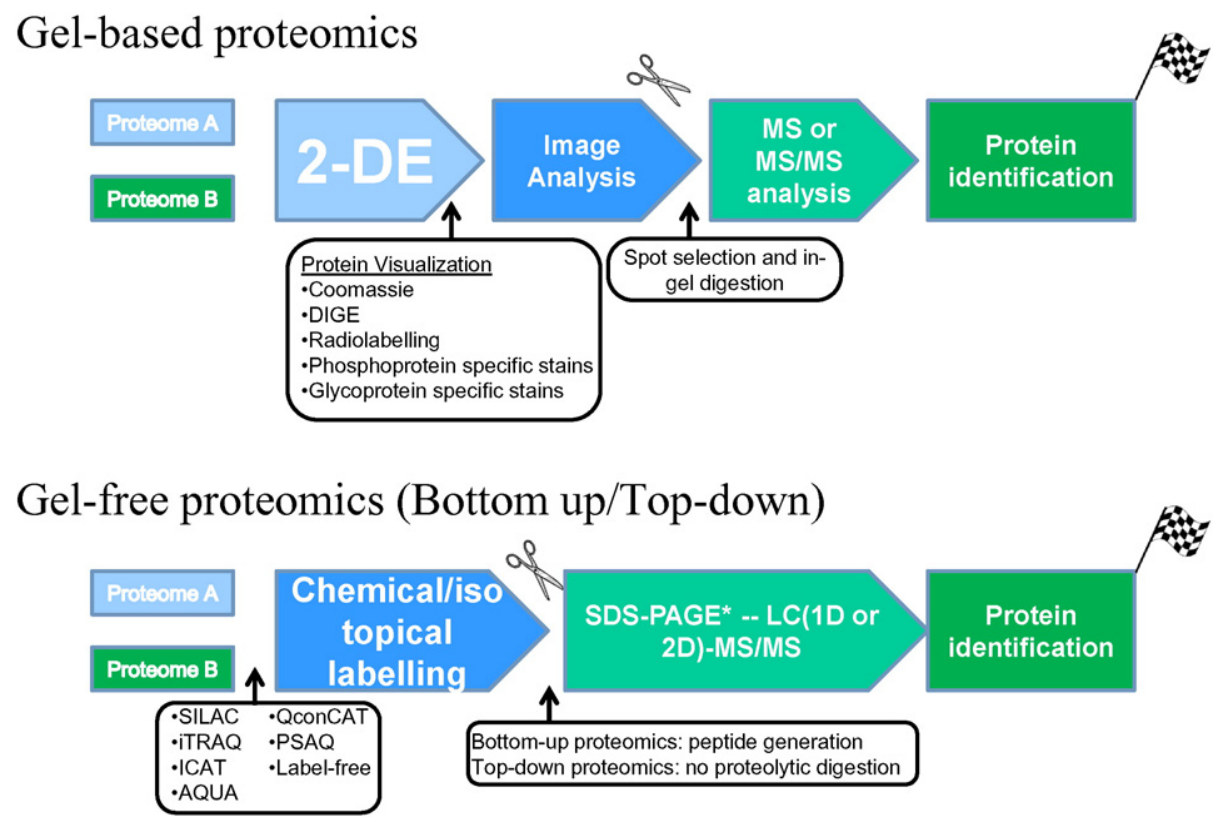

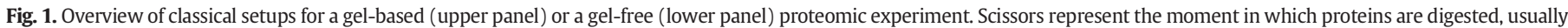
with trypsin. *Additionally, classical SDS-PAGE fractionation can be performed prior LC-MS/MS analysis.

proprietary, open-source or in-house scripts/pipelines/software are developed allowing protein identification. In this review we will focus on the most useful proteomic methods and their application in the probiotics field.

\subsection{Gel-based proteomics}

Traditionally, polyacrylamide gel electrophoresis has been used to set up differences between proteomes. The two dimensional polyacrylamide gel electrophoresis (2DE) [34] allows resolving complete proteomes into individual spots corresponding in most cases to a single protein, obtaining a kind of protein barcode of the sample. A staining protocol is then applied to the gels (Coomassie, silver etc.) allowing the visualization of the spots, which are further picked up from the gel and treated with proteases to release protein-specific peptides; these peptides are finally identified by mass spectrometry. Other possibility to detect proteins produced/repressed/degraded under certain experimental conditions is to include radioactive-labelled amino acids in the growth medium compared to control conditions [35]. These amino acids will be incorporated into newly synthesised proteins, and in this way proteins that are synthesised after for instance a stress challenge will display radioactivity and can be visualized in the gel. In addition, radiolabelling is one of the most sensitive protein detection methods, allowing detection of low-abundant proteins.

Use of 2DE is a widespread technique for massive eukaryotic and prokaryotic protein identification due to the powerful results obtained with relatively low cost compared to other gel-free techniques. However, 2DE presents some disadvantages such as reproducibility limitations, and is often insensitive to low abundant proteins such as regulators, membrane associated proteins or basic proteins. Some modifications of the protocols have been assayed in order to improve the migration of those specific protein subsets [36]. For instance hydrophobic proteins, mainly membrane-associated or membrane-integral proteins, are not well solubilized in the absence of detergents, and those detergents such as SDS are not compatible with IEF [37]. In this sense new zwitterionic detergents such as sulfobetaines have been included to improve solubilisation of hydrophobic proteins. Very alkaline proteins $(\mathrm{pI}>7$ ) are problematic in terms of resolution, resulting in poor $2 \mathrm{D}$ patterns. A method for improving the resolution of the alkaline proteome of the lactic acid bacterium Lactobacillus hilgardii, has been optimized using a combination of cup loading for sample loading and use of different reducing agents [38]. In the case of alkaline proteomes use of wide $\mathrm{pH}$ gradients in the first dimension step, inclusion of higher concentrations of reducing agents such as dithiothreitol in the cathode or alkylation of thiol groups with iodoacetamide before protein loading in the IEF step often offers substantial improvements in the separation of these proteins. In the case of low-abundant proteins, use of ultrazoom gels covering a wide range of isoelectric points, use of sensitive protein stains or labels such as radiolabelling, or inclusion of prefractionation steps during sample preparation solve in part the problem of detecting these minority proteins [36].

A variation of 2DE is the use of fluorescent dyes to label proteins during the separation process, allowing detection of low-abundant proteins and sample multiplexing. This technique is denominated 2D-difference in gel electrophoresis (DIGE) that was firstly described by Ünlü and coworkers [39]. The use of this method improves the dynamic range in protein detection, increasing the linearity relationship between protein concentration and fluorescent signal. In addition, DIGE reduces the number of experiments required for sample comparison in different experimental conditions, as many samples can be loaded in the same gel using different fluorescent dyes.

Gel-based proteomics have been used in the field of probiotics to a) obtain systematic maps for taxonomy or protein function prediction and to b) analyse differential protein expression under different environmental situations or stress conditions. In this sense, the stress response to acid conditions or bile presence has been studied by several authors $[23,24,40,41]$, as well as the different behaviour of strains when co-cultivated with other bacteria [42] or with different carbon sources [43]. The adhesion capability is another desired probiotic trait that has been tested through gel-based proteomics [44]. Gel-based proteomics have also been used to compare bacterial polymorphisms between closely related strains $[45,46]$ and to identify protein features responsible for adaptations to the gastro intestinal tract conditions [47-49].

\subsection{Gel-free proteomics}

Some of the limitations of 2DE have been solved by gel-free proteomic techniques. In gel-free proteomics, the pool of proteins present in a protein extract is reduced to small peptides through an enzymatic 
digestion with proteolytic enzymes, usually trypsin. Subsequently, peptides are separated and identified using multi-dimensional liquid chromatography systems coupled to tandem mass spectrometers (LC-MS/ MS). As peptides can be easily separated by liquid chromatography, this technique is notably faster and cheaper than 2DE. Among the techniques used for separating peptides, Ion-Exchange Chromatography, Reversed-Phase Chromatography, Size exclusion Chromatography, 2D liquid chromatography (orthogonal combinations of two out of the three mentioned chromatography systems) or OFFGEL Electrophoresis (liquid-phase peptide IEF) are worth mentioning [30].

Gel-free proteomics have become a powerful technique to analyse proteins with low abundance in complex samples, which pass undetected in gel-based proteomics. Moreover, this methodology provides more sensitive and more accurate protein quantification, as well as the possibility to identify highly hydrophobic or basic proteins. Modifications in the protein affecting relative mass or isoelectric point are not considered in gel-free techniques, which are based on protein identification through amino acid sequence determination. For that reason, gel-free proteomics are very accurate for the identification of the precise amino acid sequence of the original protein but they have limitations related to the identification of post-translational modifications. Phosphorylation or glycosylation are really important in protein function, and as they produce changes in the molecular mass (glycosylation) or protein charge (phosphorylation) they are more easily identified by 2DE. In addition, there are dyes specifically designed to visually detect phosphorylated or glycosylated proteins.

The huge progress of mass spectrometry has allowed designing techniques for quantitative gel-free proteomics. Labelling can be as easy as profiting from the proteolytic step during peptide generation to introduce one atom of 180 . This is a system to incorporate, for instance, 180 at lysine and arginine through trypsin digestion in presence of heavy water $\left(\mathrm{H}_{2} 180\right)$ [50]. Bacterial metabolism can be profited to introduce a metabolic tag in the form of inorganic salt. For instance, a $15 \mathrm{~N}$ labelled inorganic salt such as $\mathrm{K}^{15 \mathrm{NO}_{3}}$ can be used to introduce a $15 \mathrm{~N}$ label in a given experimental condition, and then compared to its $14 \mathrm{~N}$ label counterpart [51].

Other technologies are mainly based in isotopic protein labelling. In the SILAC technique (Stable Isotope Labelling with Amino acids in Cell culture) light or heavy amino acid isotopes are employed for protein labelling as they are incorporated during bacterial growth [52]. In other technique denominated ICAT (Isotope-Coded Affinity Tags), cysteinecontaining proteins are labelled with molecular tags containing either eight deuterium or hydrogen carbons [53]. ICPL or Isotope-Coded Protein Labelling, all free amino acid groups are labelled with molecular tags containing 4 hydrogen or deuterium atoms. In the case of iTRAQ (Isobaric Tags for Relative and Absolute Quantification), peptides rather than proteins are labelled with up to eight different molecular tags ranging from $145 \mathrm{Da}$ to $304 \mathrm{Da}$, allowing multiplexing up to eight different samples [54]. One modification of iTRAQ is the use of Tandem Mass Tags (TMT), in which proteins are marked with different isotopomer labels. Proteins are then digested and the incorporation of the isobaric tags into the released peptides and in the daughter peptides (originated after a full MS/MS scans) is finally measured [55]. All these labelling techniques allow quantifying different protein concentrations as affected by the experimental conditions.

Other block of gel-free technologies includes the analysis of the dilution of a known peptide within the experimental peptide mix to achieve absolute quantification of proteins. This is performed through the use of isotope-labelled internal standards [56]. In the PSAQ technique (Protein Standard Absolute Quantification) the internal standard is the target protein which is isotope-labelled and added into the sample before protein digestion [57]. In QconCAT ("Quantification concatamer") the internal standard is a chimerical protein formed by one of more isotopelabelled of the target protein, which are added also before the protein digestion step [58]. On the contrary, the AQUA system (Absolute Quantification) are a set of synthetic isotope-labelled peptides whose sequences are obtained from the proteolytic peptides of the target protein/proteins, and which are added to the sample after the peptide generation [59]. Finally, many label-free approaches have been developed profiting from the increasing detection power of the new MS detectors; detecting almost all peptides in a sample is currently use to develop algorithms able to obtain comparison of relative protein concentrations between few samples [60].

Gel-free proteomic approaches have been used in the field of probiotics to study stress response, like acid tolerance in the genus Lactobacillus [61,62] and heat shock resistance in Bifidobacterium longum [63]. Pili, which are surface proteins with important roles in the adhesion to epithelial cells and in the persistence of a probiotic bacterium in the human GIT, have been detected in Lactococcus using gel-free techniques [64]. These techniques have also been used to compare the presence/absence of pathogenic factors between food and clinical isolates [65]. In food industry, Capillary electrophoresis (CE)/MS has been used to measure the consistency of different lots of probiotic formulation [66].

Wolf and co-workers showed that the combination of both approaches increase between 2 and 3 times the number of proteins identified [67]. In this way gel-based combined with gel-free approaches have been used for food analyses and nutrition research [68,69]. It seems that both methodologies, gel and non-gel based, are complementary and should be used together whenever possible.

\section{Adaptation of probiotics to environment}

Proteomics allows high-throughput identification of key proteins for probiotic interaction with their environment, including food matrix and host intestine (Table 1). This knowledge is fundamental to understand probiotic mechanisms of action and design better functional supplements. It also provides a unique framework to identify posttranslational modifications (methylation, phosphorylation or glycosylation) that may strongly affect protein functionality but are overlooked by other "-omic" techniques [70].

\subsection{Adaptation to food}

Probiotics incorporated into food products face various challenges (freeze-drying, refrigeration temperatures, osmotic stress or acid $\mathrm{pH}$, among others) that compromise their viability and functionality. Proteomic studies on technological-related stresses shed light on key molecular mechanisms behind microbial response and adaptation to food.

Fermented products, characterized by an acid $\mathrm{pH}$, are a common delivery food for probiotics. Therefore the response of probiotic strains to acid stress is one of the most widely studied. Proteomics has been used to delineate the molecular components of the acid tolerance response (ATR) in Lactobacillus [61,71-74], Bifidobacterium [48,75,76] and Propionibacterium [77] strains. Common elements of the ATR in these bacteria, include increasing energy production through glycolysis augmentation; and counteracting $\mathrm{H}^{+}$excess by reducing endogenous production of organic acids, or increasing $\mathrm{NH}_{4}^{+}$production or $\mathrm{H}^{+}$ extrusion. Specific molecular mechanisms to achieve these metabolic adaptations are species/strain-dependent. For instance, an increment in enzymes responsible for branched chain and sulfur-containing amino-acids biosynthesis was found upon acid adaptation in B longum subsp. longum [48]; whereas L. casei metabolic rearrangements affected carbohydrate metabolism exclusively [73]. Proteins involved in general stress responses, like DnaK, GroES and GroEl are commonly overproduced following acid exposure. Despite the fact that ATR seems to be multifactorial, a two component system and a transcriptional regulator, Ldb0677, have been revealed as central regulators orchestrating ATR in Lb. delbrueckii [71,78].

Research into proteomic changes accomplished during probiotics inclusion in food products as compared to laboratory conditions, has identified key proteins for an effective adaptation of probiotics to food. 
Table 1

Studies addressing probiotics response and adaptation to relevant environmental factors through proteomic techniques.

\begin{tabular}{|c|c|c|c|}
\hline Species & Technique & Main outcome & Reference \\
\hline \multicolumn{4}{|l|}{ Technological stress } \\
\hline B. longum & 2D-PAGE \& MALDI-TOF-MS & Oxygen exposure promoted oxidative-stress protective DNA repairing mechanisms & {$[86]$} \\
\hline \multirow[t]{2}{*}{ B. longum } & [S35]methionine labelling & Common aspects of proteomic response to bile and heat stresses & [35] \\
\hline & +2D-PAGE \& MALDI-TOF-MS & $\begin{array}{l}\text { Heat shock induced protein spots with varying molecular mass and pI, that corresponded to various } \\
\text { isoforms of HtrA }\end{array}$ & \\
\hline Lb. bulgaricus & 2D-DIGE \& MALDI-TOF-MS & $\begin{array}{l}\text { Osmotic stress induced biosynthetic enzymes to produce oxidative-protective mechanisms (i.e. trehonine, } \\
\text { vit B6) and proteins for nucleotide and fatty acids biosynthesis }\end{array}$ & [87] \\
\hline Lb. casei & SPS-PAGE \& MALDI-TOF-MS & $\begin{array}{l}\text { Starved cells switch metabolism towards scavenging, promoting gluconeogenesis, amino acids synthesis } \\
\text { or intermediate metabolism }\end{array}$ & {$[85]$} \\
\hline Lb. casei & LC-MS/MS & $\begin{array}{l}\text { Starved cells switch metabolism towards scavenging, promoting gluconeogenesis, amino acids synthesis } \\
\text { or intermediate metabolism }\end{array}$ & {$[110]$} \\
\hline Lb. plantarum & 2D-PAGE & Food-like conditions affected stress response, carbohydrate and nitrogen metabolism & [79] \\
\hline Lb. plantarum & 2D-PAGE \& MALDI-TOF-MS & $\begin{array}{l}\text { Described heat-response of the CtsR regulon at proteomic level } \\
\text { Identified potential ClpE isoforms with different molecular mass }\end{array}$ & {$[88]$} \\
\hline Lb. rhamnosus & 2D-PAGE \& MALDI-TOF-MS & $\begin{array}{l}\text { Cheese-like media adaptation modulates proteome towards induced nitrogen metabolism and decreases } \\
\text { sugar metabolism }\end{array}$ & {$[80]$} \\
\hline Lb. rhamnosus & 2D-DIGE \& MALDI-TOF-MS & $\begin{array}{l}\text { Industrial-type whey-based medium increases nitrogen and fatty acids metabolism and reduces } \\
\text { exopolysaccharides biosynthesis } \\
\text { Production of activities of interest (e.g. proteolytic activities) is media-dependent }\end{array}$ & {$[82]$} \\
\hline Lb. sanfranciscensis & 2D-PAGE \& MALDI-TOF-MS & Proteomic response to high hydrostatic pressure overlap with cold and osmotic stresses & {$[90]$} \\
\hline Lc. casei & 2D-PAGE \& MALDI-TOF-MS & Overproduced proteins in lactose-starved cells improve bacterial survival under a range stress-factors & [84] \\
\hline P. freudenreichii & 2D-PAGE \& MALDI-TOF-MS & $\begin{array}{l}\text { Cheese ripening in the cold augments proteins for glycogen accumulation and alternative carbon sources } \\
\text { utilization, favoring its long-term survival }\end{array}$ & [81] \\
\hline P. freudenreichii & 2D-PAGE \& MALDI-TOF-MS & $\begin{array}{l}\text { Heat adapted strains overproduced proteins related to stress response, sulfur-metabolism and propionic } \\
\text { fermentation }\end{array}$ & [89] \\
\hline \multicolumn{4}{|l|}{ Acid stress } \\
\hline B. longum & 2D-PAGE \& MALDI-TOF-MS & $\begin{array}{l}\text { Acid pre-stressing enhanced protein protection, acid counteraction and peptidoglycan synthesis during a } \\
\text { second acid challenge, explaining better survival after second acid challenge }\end{array}$ & [75] \\
\hline B. longum & 2D-PAGE \& MALDI-TOF-MS & Stationary phase cells overproduced proteins protecting against an acid challenge & [76] \\
\hline \multirow[t]{2}{*}{ B. longum } & 2D-PAGE\& MALDI-TOF-MS & Acid response and adaptation involve different mechanisms & {$[48]$} \\
\hline & & Acid response induces overproduction of proteins that might provide adaptation to intestinal factors & \\
\hline Lb. casei & 2D-PAGE \& MALDI-TOF-MS & $\begin{array}{l}\text { Carbohydrate metabolism and general stress response proteins are overproduced following acid } \\
\text { adaptation }\end{array}$ & [73] \\
\hline $\begin{array}{l}\text { Lb. delbrueckii } \\
\text { subsp. bulgaricus }\end{array}$ & 2D-PAGE \& MALDI-TOF-MS & Novel acid-inducible transcriptional regulator identified as central regulator of acid stress response & [99] \\
\hline $\begin{array}{l}\text { Lb. delbrueckii } \\
\text { subsp. bulgaricus }\end{array}$ & 2D-PAGE\& MALDI-TOF-MS & $\begin{array}{l}\text { Acid adaptation induced general stress response and fatty acid biosynthesis, and repressed the mevalonate } \\
\text { pathway of isoprenoid synthesis }\end{array}$ & [74] \\
\hline \multirow[t]{2}{*}{ Lb. plantarum } & LC-MS/MS & $\begin{array}{l}\text { Acid inhibited catabolite repression and promoted oxidative stress responses and acidification } \\
\text { counteracting mechanisms }\end{array}$ & {$[61]$} \\
\hline & & Previously uncharacterized proteins overproduced in acid & \\
\hline Lb. reuteri & 2D-PAGE \& MALDI-TOF-MS & Acid exposure up-regulates carbohydrates metabolism and general stress response & [72] \\
\hline P. freudenreichii & 2D-PAGE \& MALDI-TOF-MS & Described interconnection among the responses to acid, bile salts and heat stresses at proteomic level & [77] \\
\hline \multicolumn{4}{|c|}{ Bile and other gastrointestinal stresses } \\
\hline $\begin{array}{l}\text { B. animalis subsp. } \\
\text { lactis }\end{array}$ & 2D-PAGE \& MALDI-TOF-MS & $\begin{array}{l}\text { Overlap between bile response and adaptation mechanisms described at energetic, oxidative and } \\
\text { biosynthetic levels }\end{array}$ & [47] \\
\hline B. longum & 2D-PAGE \& MALDI-TOF-MS & $\begin{array}{l}\text { Bile salts promote accumulation of moonlighting adhesion-like factors, including DnaK and enolase, in } \\
\text { surface associated proteome }\end{array}$ & [136] \\
\hline B. longum & 2D-DIGE \& MALDI-TOF-MS & $\begin{array}{l}\text { Bile promotes accumulation of moonlighting adhesion-like factors, including enolase and GAPDH, in } \\
\text { surface associated proteome }\end{array}$ & [98] \\
\hline \multirow[t]{2}{*}{ B. longum } & 2D-PAGE \& MALDI-TOF-MS & $\begin{array}{l}\text { Exposure to a rabbit intestine promoted accumulation of adhesin-like factors, stress related proteins and } \\
\text { quorum sensing mediators }\end{array}$ & [103] \\
\hline & & Evident post-translational modification of several proteins & \\
\hline \multirow[t]{2}{*}{ B. longum } & 2D-PAGE \& MALDI-TOF-MS & Detailed model of bile response based on combined and proteomic and transcriptomic analysis & [99] \\
\hline & & $\begin{array}{l}\text { Bile detoxification mechanisms, central metabolism and regulatory proteins bile-modulated were } \\
\text { identified }\end{array}$ & \\
\hline B. longum & 2D-PAGE \& MALDI-TOF-MS & Bile modulates energetic metabolism, stress response and DNA protection mechanisms & [49] \\
\hline \multirow[t]{2}{*}{ Lb. acidophilus } & 2D-PAGE \& MALDI-TOF-MS & Adhesion factors identified in the cell-wall associated proteome & [143] \\
\hline & & Cell-wall proteome variations identified between strains & \\
\hline Lb. casei & 2DE \& chip-LC-QTOF-MS/MS & Proteomic overlap between bile response and adaptation utilized to identify bile tolerance markers & {$[41]$} \\
\hline Lb. casei & 2D-PAGE \& MALDI-TOF-MS & Bile response induced proteins involved in stress response, carbohydrates metabolism and & {$[40]$} \\
\hline Lb. casei & 2D-PAGE \& MALDI-TOF-MS & $\begin{array}{l}\text { Provided overview of metabolic functions regulated by high-concentrations of bile, which include } \\
\text { carbohydrate, nucleotide and fatty acid metabolism, amino acid biosynthesis, transcription, translation } \\
\text { and general stress response }\end{array}$ & {$[100]$} \\
\hline $\begin{array}{l}\text { Lb. delbrueckii } \\
\text { subsp. lactis }\end{array}$ & 2D-PAGE \& MALDI-TOF-MS & Bile-induced proteome changes reflect modification of cell-envelope synthesis and surface characteristics & [101] \\
\hline \multirow[t]{2}{*}{ Lb. johnsonii } & ITRAQ \& LC-MS/MS & Physiological response to bile characterized & [97] \\
\hline & & Biosynthesis mechanisms are repressed and functions to sustain cell viability, induced & \\
\hline Lb. rhamnosus & 2D-DIGE \& MALDI-TOF-MS & $\begin{array}{l}\text { Bile response induced functions relevant for intestinal adaptation like membrane associated functions, } \\
\mathrm{BSH} \text {, multidrug resistance mechanisms and two-component systems }\end{array}$ & [102] \\
\hline Lc. lactis & LC-MS/MS & Pili identified as adhesion factors in surface-associated proteome & [64] \\
\hline
\end{tabular}


Siragusa et al. [79] mimicked in vitro food fermentations to reveal that Lactobacillus plantarum adjusts its metabolism to the carbohydrates available in the food matrix. Furthermore, reduction in enzymes connected with lactic acid production (i.e. glycolysis) and increase in the synthesis of proteins involved in fatty acids biosynthesis was observed in fermented foods, supporting in vitro observations in acidified MRS broth, which is a complex medium used to growth lactic acid bacteria [61]. Similar proteomic experiments were performed on Lb. rhamnosus and Propionibacterium freudenreichii grown under simulated industrial conditions as compared to laboratory MRS [80-82]. Their results evidenced strong differences between the metabolic pathways activated in MRS, where glucose and lactose are abundant and lactic acid is the major metabolic end product, and those activated in "cheese-like" broth, where carbohydrates are scarce and fatty acids abundant, and metabolism is directed towards and increased acetic acid production.

Indeed, carbohydrate starvation is a common food stress for probiotic bacteria and proteomic analysis of nutrient-deprived lactobacilli evidenced metabolic activation of routes to metabolize alternative carbon sources. Increased production of general stress response proteins is also observed, and would contribute to the higher tolerance of nutrient-deprived cells to various stresses [83-85].

Proteomics has also been used to study probiotics response to other food associated stress factors including oxidative stress [86]; osmotic stress [87]; heat stress [35,88,89]; high pressures [90]; or the presence of dietary components such as prebiotic ingredients [43,91-94] or bioactive dietary polyphenols like rutin [95].

\subsection{Adaptation to the intestinal environment}

Intestinal colonization is considered a requisite for probiotics health promotion [6]. Gastrointestinal passage imposes important challenges for probiotic survival, like acidity in the stomach or the presence of bile salts and digestive proteases in the intestine. Furthermore, probiotics encounter a densely populated microbial ecosystem in the large intestine, where they need to compete against autochthonous microbiota to colonize the intestinal environment. Proteomics under in vitro conditions mimicking GIT environments or using in vivo models have revealed some of the mechanisms behind probiotics adaptation to the intestinal environment.

Proteomics have helped in understanding the response and adaptation of probiotic bacteria to bile. Bile salts are biological detergents which participate in fat emulsion and absorption. They can also disrupt and destabilize bacterial membranes, leading to ions leaking, proteins miss-folding and aggregation and cell death. Accordingly, bile exposure generally translates into overproduction of ribosomal and general stress response proteins, as a mean to promote protein recycling; as well as energy production systems and proteins involved in membrane and cell wall biosynthesis, reflecting the need to counteract membrane damage [35,40,47,49,96-102].

Other proteins involved in the response mechanism to bile in other probiotic strains have been identified through proteomics. For instance, bile salt hydrolase role in bile detoxification is not clear, but it is overproduced in some Lactobacillus exposed to bile [96,97,102], and in a B. longum strain exposed to a rabbit intestine [103] as revealed by different proteomic techniques. From the bifidobacterial strains tested, only one B. longum strain overproduced BSH following an in vitro bile challenge [99], but it was constitutively overproduced in a bile adapted B. animalis strain [47].

Proteomics have also contributed to characterize prebiotic utilization pathways availing better symbiotics design. Probiotic bacteria are adapted to utilize a range of carbon sources that, otherwise, would be undigested by their hosts, favoring their establishment in the intestinal environment. For instance, $\beta$-glucans and xylo-oligosaccharides utilization pathways in bifidobacteria [91-93]; lactitol and cellobiose

Table 2

Studies addressing probiotic functionality through proteomic techniques.

\begin{tabular}{|c|c|c|c|}
\hline Species & Technique & Main outcome & Reference \\
\hline $\begin{array}{l}\text { B. animalis } \\
\text { subsp. lactis }\end{array}$ & 2D-DIGE \& MALDI-TOF-MS & Xylo-oligosacharides utilization model proposed from proteomic profiles & [92] \\
\hline $\begin{array}{l}\text { B. animalis } \\
\text { subsp. lactis }\end{array}$ & LC-ESI-Q-TOF MS/MS & $\begin{array}{l}\text { Membrane-associated proteome, includes carbohydrate import mechanisms, adhesin-like factors } \\
\text { and immunoregulatory proteins }\end{array}$ & [93] \\
\hline B. breve & 2D-DIGE \& MALDI-TOF-MS/MS & $\begin{array}{l}\text { Intestinal cells co-cultivated with } B \text {. breve overproduced cytoskeleton elements, presumably } \\
\text { strengthening the epithelial barrier }\end{array}$ & [118] \\
\hline B. longum & 2D-DIGE \& MALDI-TOF-MS & B-glucans utilization model proposed from proteomic profiles & [91] \\
\hline B. longum & 2D-PAGE \& MALDI-TOF-MS & $\begin{array}{l}\text { Probiotic administration to gliadin-induced enteropathy rat model modulates jejunal proteome, } \\
\text { partially counteracting the gliadin-induced inflammatory changes }\end{array}$ & [106] \\
\hline \multirow[t]{2}{*}{ B. longum } & \multirow[t]{2}{*}{ 2D-PAGE \& MALDI-TOF-MS } & Identified plasminogen binding proteins in cytoplasmic proteome & \multirow[t]{2}{*}{ [133] } \\
\hline & & $\begin{array}{l}\text { Co-culture with intestinal cells induces overproduction of proteins including several moonlighting } \\
\text { adhesin-like factors }\end{array}$ & \\
\hline B. longum & 2D-PAGE \& MALDI-TOF-MS & $\begin{array}{l}\text { Probiotic administration partially counteracted gliadin-induced proteome changes at jejunal level in } \\
\text { a gliadin-induced enteropathy rat model }\end{array}$ & [106] \\
\hline Lb. acidophilus & 2D-DIGE \& MALDI-TOF-MS & Proposed molecular model for lactitol metabolism & [94] \\
\hline Lb. acidophilus & 2D-DIGE \& MALDI-TOF-MS & Identified molecules involved in cellobiose metabolism & [43] \\
\hline Lb. acidophilus & 2D-PAGE \& MALDI-TOF-MS & $\begin{array}{l}\text { In acid pH, cell wall associated GroES and GroEL augment, correlating to induction of altered } \\
\text { cytokine secretion pattern in splenocytes }\end{array}$ & [135] \\
\hline Lb. acidophilus & 2D-PAGE \& MALDI-TOF-MS & $\begin{array}{l}\text { Identified proteins overproduced following growth in cholesterol and elements presumably } \\
\text { involved in cholesterol reducing capability }\end{array}$ & [107] \\
\hline Lb. acidophilus & 2D-PAGE \& MALDI-TOF-MS & $\begin{array}{l}\text { Identified elements regulated by } \mathrm{CcpA} \text {, that might be important for the cholesterol reducing } \\
\text { capability of the strain }\end{array}$ & [108] \\
\hline Lb. fermentum & 2D-PAGE & $\begin{array}{l}\text { Co-administration of } L b \text {. fermentum and aureomycin to piglets counteracted the antibiotic effects on } \\
\text { the intestinal proteome }\end{array}$ & [113] \\
\hline Lb. plantarum & LC-MS/MS & Identified surface-proteome changes in a sortase-mutant with increased pro-inflammatory signaling & [131] \\
\hline Lb. plantarum & $\begin{array}{l}\text { 2D-PAGE \& MALDI-TOF-MS/MS or MDLC } \\
\text { coupled to nano-ESI-MS/MS }\end{array}$ & $\begin{array}{l}\text { Quorum sensing regulates adhesion factors correlating to increased biofilm formation, intestinal } \\
\text { binding and pathogens exclusion }\end{array}$ & [111] \\
\hline Lb. rhamnosus & LC-MS/MS & $\begin{array}{l}\text { Surface-associated proteome includes moonlighting protein with predicted functions in adhesion, } \\
\text { immuno-stimulation and pathogens exclusion }\end{array}$ & [26] \\
\hline Lb. rhamnosus & 2D-PAGE \& MALDI-TOF-MS & $\begin{array}{l}\text { Growth in mucin resulted in reduced production of secreted proteins and production of previously } \\
\text { unknown extracellular proteins }\end{array}$ & [137] \\
\hline P. freudenreichii & LC-MS/MS and nano-LC-MS/MS & Identify adhesion and immunomodulation determinants & [22] \\
\hline
\end{tabular}


utilization pathways in lactobacilli $[43,94]$; and human milk oligosaccharides metabolizing capabilities in infant-associated bifidobacteria [104] have been studied through proteomics.

\section{Proteomics for the study of changes in probiotic functionality}

The pool of proteins produced by a microorganism at certain growth stage is highly influenced by environmental factors and therefore, production of key proteins for probiotics adaptation and functionality may vary under specific conditions (Table 2). Proteomics helps discern probiotic attributes modulation by environmental factors [31,105], but also their effect on the intestinal cells proteome and gut metaproteome [106].

Intestinal factors auto-regulate probiotic traits, for instance cholesterol and bile salts induce the metabolic enzymes required for the cholesterol reducing capability of $L b$. acidophilus strains. Proteins overproduced in the presence of cholesterol [107]; and proteins reduced in a carbon control protein A ( $c c p A)$ mutant, defective for its cholesterol reducing ability [108], have been discerned through proteomics. Another example of environmental regulation of probiotic traits is the overproduction of endopeptidases PepE and PepO, known to be essential for producing the angiotensin conversion inhibitory peptide, following Lb. rhamnosus growth in soya milk or Lb. helveticus growth in skim milk [80,109]. Indeed, lactobacillus incubation in milk at refrigeration temperatures overproduced factors, related to amino acids metabolism and DNA protection, that also enhanced bacterial persistence in the mammalian digestive tract [110], thus highlighting the importance of food matrix selection on probiotics functionality.

At intestinal level probiotics not only interact with host cells but with other members of the microbiota. In this context, proteomic analysis revealed overproduction of the quorum sensing mediator LuxS in $B$. longum upon incubation in a rabbit intestine [103], pointing to the existence of a cross-talk with other gut bacteria. Indeed, co-culture of $L b$. sanfranciscensis with $L b$. plantarum or with its signaling peptide plantaricin, promoted over-representation of adhesion factors in the cell envelope [111].

Proteomics studies have also focused on changes in intestinal proteomes in response to the presence of probiotics. In vitro, a Bifidobacterium breve strain promoted overproduction of components of the cytoskeleton and major histocompatibility complex in HT29 cells [112]. In vivo models with weaning piglets also revealed that probiotic and antibiotics administration promoted differential changes in the small intestinal proteome [113]. Models of intestinal diseases have also studied probiotics action at proteomic level. For instance, a jejunal proteome analysis in a rat model of gliadin-induced enteropathy revealed that $B$. longum modulates inflammation [106].

\section{Proteomics of simple and complex microbial populations: metaproteomics}

The human microbiota comprises thousands of different microorganisms that co-habit in the same environmental niche. From an analytical point of view, this fact increases notably the complexity at the level of sample processing and data analysis, and difficult massive protein identification. During the last ten years, improvements in protein/peptide separation and identification, such as the development of highresolution mass spectrometers, have allowed the study of complex protein samples [114]. The study of the proteome of environmental systems is referred to as metaproteomics, and was defined few years ago [115]. In this regard, metaproteomics of more or less simple bacterial consortia both in vitro or using gnotobiotic mice, has been invaluable for the development of methodologies allowing implementation of this technique to the study of the human microbiota [116]. In the case of probiotics, metaproteomics have a clear application in determining the effect of a given strain over the relative abundances of the microorganisms integrating the bacterial community of the human GIT.
Many of the methods used in metaproteomics have been inherited from gel-free proteomics, and needs further improvements, for instance to warrant a complete bacterial lysis [117]. For instance, a method has been recently described allowing efficient bacterial separation from the rest of faeces components, which may facilitate further protein and representative protein extraction [118]. In the field of gut microbiota, the majority of studies have been published based on DNA sequencing analyses but few studies have been performed through proteomics. In this sense, Klaassens and coworkers [119] showed that infant fecal bacterial metaproteome changed over the time, based in 2DE analyses; whereas Verberkmoes and coworkers [120] identify microbial proteins present in fecal samples based on gel-free LC-MS/MS. Metaproteomics are not still optimized in terms of resolutive power, but it has already been used for the identification of the protein core of the gut microbiota [121]. In this sense, metaproteomics has confirmed the long-term stability of the gut microbiota in adults, as suggested by other omics methodologies, identifying a core of about 1000 microbial proteins per subject, among which proteins involved in microbial-host crosstalking such as flagellins [122]. Data from other omics techniques is of great value for establishing and implementing metaproteome protocols, and indeed input from metagomics or single bacteria genomes has been shown to increase the resolution ability and the identification capacities of known identification routines through the implementation of novel data mining models [123].

Gel-free techniques have been combined with 2DE to study the whole human gut microbiota composition [120] and their modification after probiotic [32] or antibiotic administration [124]. Classical SDSPAGE has been also combined with LC-MS/MS in order to detect the gut metaproteome signature of obese vs lean subjects, generating interesting results such as the Bacteroidetes members are metabolically more active in the obese cohort [125]. Although still a nascent discipline, metaproteomics is a promising and non-invasive tool for tracing probiotic effects on the complex gut ecosystem and to study the functionality of the gut microbiota, notably in the context of autoimmune and chronic inflammatory diseases [126].

\section{Proteomics of sub-cellular fractions}

One of the possibilities to decrease protein complexity in terms of abundance is to fraction proteomes according to subcellular locations. Proteomics has also been used for describing changes in some of these sub-proteomes, such as surface-associated proteins [127] or extracellular proteins [128], which are the first steps to identify molecules involved in the interaction of probiotic bacteria with the human host [129].

In this way, surface associated and extracellular proteomes are relevant for a probiotic since they will determine the type of interaction with the human host, and ultimately the mechanism of action [130]. Surface associated proteins initiate the dynamic molecular dialogue bacteria-host and, therefore, can have crucial roles for probiotics functionality. Surface exposed and secreted proteins have been attributed roles in intestinal attachment, and immunomodulation in Lactobacillus, Propionibacterium and Bifidobacterium strains [22,26]. Indeed, sortase dependent proteins appeared to be essential for the immunomodulatory properties and gut retention of $L b$. plantarum [131,132]. Furthermore, surface-exposed or secreted proteomes are often modulated by intestinal factors like co-culture with intestinal cell lines [133], low pH [134, $135]$, bile salts $[72,98,136]$ or mucin $[137,138]$, or co-cultivation in a caecum-like environment [139], thus pointing to intestinal regulation of functions crucial for probiotics intestinal colonization. Indeed, implantation of a $B$. longum culture into a rabbit intestine confirmed in vivo over-production of elongation factor Tu [103].

Several proteinaceous factors involved in probiotic attachment to intestinal cell lines in vitro have been identified in the surface associated proteome. Among them, internalin A in Propionibacterium freudenreichii [22], BopA in Bifidobacterium bifidum [140], pilus-like structures in LC 
lactis [64], bifidobacteria [141] and lactobacilli [142], S-layer proteins (slpA) in Lb. acidophilus [143] or fimbriae in Lb. rhamnosus [144] are remarkable and have been identified using proteomic approaches. In this sense, proteomics has been relevant in the identification a high number of moonlighting proteins, proteins that are secreted without harbouring any signal peptide. Apart from being important metabolic proteins, they have been shown to be associated to the bacterial surface displaying plasminogen or mucin binding activities. Examples of moonlighting proteins are enzymes involved in carbohydrate metabolism like enolase or glyceraldehyde 3-phosphate dehydrogenase (GADPH), general stress proteins like DnaK, GroES or GroEL and elongation factors such as EF-Tu, which in some cases appeared overproduced following bile exposure $[133,136,137,145,146]$.

\section{Bioinformatics tools}

Today, more than ever, the study of human microbiome and probiotic functionality attracts considerable attention from the bioinformatics community. Late in 2000s, the Human Microbiome Project (HMP) [147] and the metagenomics of the Human Intestinal Tract (MetaHit) [148] emerged as the two main international initiatives devoted to the study of human microbiome and the development of computational methods to analyse sequenced metagenomes. Now, the spectrum of software tools dedicated or supporting these analyses is quite vast.

Many efforts have been devoted to gene function prediction, notably in probiotic research, where very specific effects are observed in concise strains harbouring certain genetic traits. Regarding the gut microbiome, approximately $50 \%$ of the genes are not yet characterized using standard annotation methods [149]. Therefore, conventional methods for putative gene characterization and functional prediction, based on alignment to homologous genes with existing annotations (e.g. BLAST), were rendered ineffective [150]. Alternative computational methods approached the problem by integrating standard homologybased with additional information, namely sequence features, coexpression data, protein-protein interactions, binding sites, and subcellular localisation data.

The annotation pipelines of RAST, MG-RAST [151] and IMG/M [152] are perhaps the most well-known comparative genomics-based automated pipelines where researchers working on probiotics or gut microbiota can easily analyse genomes/metagenomes. Databases such as Pfam [150] and COG [153] enable methods encompassing comparisons with sequence-diverse protein families or recurring sequence motifs; and, the KEGG Orthology and KEGG pathways databases [154] are often used to predict the composition ratio of microbial gene families and pathways from the human microbiome project $[155,156]$. Tools such as RAPSearch [157] and PAUDA [158] propose faster alternatives than BLAST to the alignment of environmental sequencing reads. Besides comparative genomics, there are structure-based approaches, functional prediction methods based on evolutionary conservation and phylogeny, and network context-based approaches (e.g. coexpression and metabolic networks) $[156,159,160]$.

Regarding proteomics software packages two open source tools, Unipept and MetaProteomeAnalyzer, are worth mentioning. Unipept is a web application powered by the UniProt database and an implementation of a custom lowest common ancestor algorithm [161]. It allows tryptic peptide and metaproteome analysis or identification of unique tryptic peptides in a given sample/experimental condition, highly valuable in targeted proteomics. In addition, it provides a set of interactive data visualizations such as the metaproteome clustering tool. The MetaProteomeAnalyzer is a software package dedicated to the integration of metaproteomic profiles with other metadata (genomic, functional etc.). This tool provides with an intuitive environment for data mining, analysis and interpretation, as well as with methodologies to decrease data redundancy [162].

During the next years, further improvements in protein database searching, raw mass spectra filtering, data mining and graphical representation among other computational processes, will allow determining how gut metaproteome composition affects human health through bottom-up or top-down methodologies allowing discovering over or sub-representation of key metabolic pathways/features through high-throughput and non-invasive techniques.

Human gut metaproteomics is also an emerging research field that is characterized by a high level of complexity $[163,164]$. Conventional high-throughput spectral interpretation algorithms have been developed in the context of properly assigning peptide-spectral masses or peptide sequence information (inferred from MS/MS fragmentation) to the proteins from which peptides are theoretically derived. In addition, there are many ambiguous peptides that can be derived from different proteins [165]. This, also known as the protein inference problem, is an important bottleneck in shotgun proteomics which has been addressed using different strategies, such as Bayesian approaches or Lasso models $[166,167]$. The development of cross-species protein identification approaches and metagenomics-based approaches was challenged by the complexity of the gut microbial proteome and the dynamic distribution of species between individuals. New approaches aim to increase the sensitivity of the peptide identification by peptide spectrum matching and one possibility is to integrate synthetic metaproteome information and metagenomic information [123]. The work of Muth et al. [121] further discusses alternatives to the peptide identification via database searching and presents de novo sequencing as a valid alternative independent from protein sequence databases. The field of human gut microbiome metaproteomics has been recently reviewed [168].

Genome-scale metabolic models (GEMs) are perhaps the latest tool in human gut bioinformatics [169,170]. Metagenomics studies can quantify the relative abundance of each species in a community but it does not enable description of the function of each individual. The GEMs can describe the metabolism of each species and the integrated analysis of these models may allow us to explore the interactions between predominant bacteria in the gut ecosystems. For example, ElSemman and colleagues reconstructed two GEMs for Bifidobacterium adolescentis L2-32 (the iBif452 model) and Faecalibacterium prausnitzii A2-165 (the iFap484) to support the study of the anti-inflammatory role that these microorganisms play in the gut ecosystem [171]. Along this line of research, Bayesian inference of metabolic networks has been employed to reveal a metabolic system with greater prevalence among inflammatory bowel disease patients [172]; and the construction and functional analysis of proteome interaction networks enabled the analysis of nutrient-affected pathways in human pathologies [173].

\section{Conclusions and perspectives}

Traditionally, probiotics have been selected on the basis of a good technological performance, mainly their suitability to survive during industrial processing and storage, a robust metabolic behaviour that allows profitable biomass yields, and a stress resistant phenotype that guarantee their passage through the gastrointestinal tract and subsequent viability in the gut. In this regard, the molecular basis underlying the functional properties of probiotic bacteria responsible for the health promoting effects have been in the background for many years. However, the breakthrough of omics technologies in the probiotic and microbiota fields has had a very relevant impact in the elucidation of probiotic mechanisms and in the procedures to select these microorganisms, based on solid scientific evidence. During the last decade we have seen a tremendous eclosion of genomics and metagenomics methodologies that were very useful to identify the population of microbes inhabiting our gut, and its relation to different diseases and physiological disorders. It is unquestionable that, in the near future, the evolution of proteomic techniques will play a pivotal role in the generation of knowledge about the functions of probiotics and gut commensals, still a pending issue in the field of intestinal microbiomics. In addition, enrichment and curation of database content will increase the knowledge 
about functions of proteins, which is a very important aspect for proteomic analyses in general. This will include not only more efforts in curating individual (and mostly draft) probiotic genomes, but also deciphering the functions of the hypothetical or putative proteins that are distributed along all genetic entries.

\section{Conflict of interest}

The authors declare no conflict of interest in relation to the work described in this paper.

\section{Acknowledgements}

Research in our lab is funded by Grants AGL2013-44039-R and AGL2013-44761-P from the Spanish "Plan Estatal de I + D + I". Part of the authors is also partially funded by the [15VI013] ContractProgramme from the University of Vigo and the Agrupamento INBIOMED from DXPCTSUG-FEDER unha maneira de facer Europa (2012/273). Lorena Ruiz has received funding from the People Programme (Marie Curie Actions) of the European Union's Seventh Framework Programme FP7/2007-2013/under REA grant agreement $n^{\circ}$ 624773. Borja Sánchez was recipient of a Ramón y Cajal postdoctoral contract from the Spanish Ministry of Economy and Competitiveness.

\section{References}

[1] E. Metchnikoff, I.I. Metchnikoff, The Prolongation of Life: Optimistic Studies, http:// books.google.com/books?hl=en\&lr=\&id=U8bgKGvZJV0C\&pgis $=11908$.

[2] T. Matsuzaki, R. Yamazaki, S. Hashimoto, T. Yokokura, The effect of oral feeding of Lactobacillus casei strain Shirota on immunoglobulin E production in mice, J. Dairy Sci. 81 (1998) 48-53, http://dx.doi.org/10.3168/jds.S0022-0302(98)75549-3.

[3] D. Gordon, J. Macrae, D. Wheater, A Lactobacillus preparation for use with antibiotics, Lancet 269 (1957) 899-901, http://dx.doi.org/10.1016/S01406736(57)91222-9.

[4] J. Schrezenmeir, M. de Vrese, Probiotics, prebiotics, and synbiotics-approaching a definition, Am. J. Clin. Nutr. 73 (2001) 361S-3364, http://dx.doi.org/10.1007/10_ 2008_097.

[5] Fao, Probiotics in food, Food Nutr. Pap. 85 (2001) 71, http://dx.doi.org/10.1201/ 9781420009613.ch16.

[6] C. Hill, F. Guarner, G. Reid, G.R. Gibson, D.J. Merenstein, B. Pot, et al., Expert consensus document: the International Scientific Association for probiotics and prebiotics consensus statement on the scope and appropriate use of the term probiotic, Nat. Rev. Gastroenterol. Hepatol. 11 (2014) 9, http://dx.doi.org/10.1038/nrgastro.2014. 66.

[7] Z. Sun, A. Baur, D. Zhurina, J. Yuan, C.U. Riedel, Accessing the inaccessible: molecular tools for bifidobacteria, Appl. Environ. Microbiol. 78 (2012) 5035-5042, http:// dx.doi.org/10.1128/AEM.00551-12.

[8] F. Bäckhed, R.E. Ley, J.L. Sonnenburg, D.A. Peterson, J.I. Gordon, Host-bacterial mutualism in the human intestine, Science 307 (2005) 1915-1920, http://dx.doi.org/ 10.1126/science.1104816.

[9] J. Qin, R. Li, J. Raes, M. Arumugam, K.S. Burgdorf, C. Manichanh, et al., A human gut microbial gene catalogue established by metagenomic sequencing: article: nature, Nature 464 (2010) 59-65, http://dx.doi.org/10.1038/nature08821.

[10] J.K. Nicholson, E. Holmes, J. Kinross, R. Burcelin, G. Gibson, W. Jia, et al., Host-gut microbiota metabolic interactions, Science 80- (336) (2012) 1262-1267, http:// dx.doi.org/10.1126/science.1223813.

[11] H.J. Flint, K.P. Scott, P. Louis, S.H. Duncan, The role of the gut microbiota in nutrition and health, Nat. Rev. Gastroenterol. Hepatol. 9 (2012) 577-589, http://dx.doi.org/ 10.1038/nrgastro.2012.156.

[12] C. Manichanh, N. Borruel, F. Casellas, F. Guarner, The gut microbiota in IBD, Nat. Rev. Gastroenterol. Hepatol. 9 (2012) 599-608, http://dx.doi.org/10.1038/ nrgastro.2012.152.

[13] A. Hevia, C. Milani, P. López, A. Cuervo, S. Arboleya, S. Duranti, et al., Intestinal dysbiosis associated with systemic lupus erythematosus, MBio. 5 (2014), e01548-14, http://dx.doi.org/10.1128/mBio.01548-14.

[14] M. Vijay-Kumar, J.D. Aitken, F.A. Carvalho, T.C. Cullender, S. Mwangi, S. Srinivasan, et al., Metabolic syndrome and altered gut microbiota in mice lacking Toll-like receptor 5, Science 80- (328) (2010) 228-231, http://dx.doi.org/10.1126/science. 1179721.

[15] J.U. Scher, S.B. Abramson, The microbiome and rheumatoid arthritis, Nat. Rev. Rheumatol. 7 (2011) 569-578, http://dx.doi.org/10.1038/nrrheum.2011.121.

[16] L. Wen, R.E. Ley, P.Y. Volchkov, P.B. Stranges, L. Avanesyan, A.C. Stonebraker, et al., Innate immunity and intestinal microbiota in the development of Type 1 diabetes, Nature 455 (2008) 1109-1113, http://dx.doi.org/10.1038/nature07336.

[17] P.J. Turnbaugh, R.E. Ley, M.A. Mahowald, V. Magrini, E.R. Mardis, J.I. Gordon, An obesity-associated gut microbiome with increased capacity for energy harvest, Nature 444 (2006) 1027-1031, http://dx.doi.org/10.1038/nature05414.
[18] P.A. Smith, Brain, meet gut, Nature 526 (2015) 312-314, http://dx.doi.org/10.1038/ 526312a.

[19] G.P. Donaldson, S.M. Lee, S.K. Mazmanian, Gut biogeography of the bacterial microbiota, Nat. Rev. Microbiol. 14 (2015) 20-32, http://dx.doi.org/10.1038/ nrmicro3552.

[20] E.E. Hansen, C.A. Lozupone, F.E. Rey, M. Wu, J.L. Guruge, A. Narra, et al., Pangenome of the dominant human gut-associated archaeon, Methanobrevibacter smithii, studied in twins, Proc. Natl. Acad. Sci. U. S. A. 108 (Suppl.) (2011) 4599-4606, http://dx.doi.org/10.1073/pnas.1000071108.

[21] M. Arumugam, J. Raes, E. Pelletier, D. Le Paslier, T. Yamada, D.R. Mende, et al., Enterotypes of the human gut microbiome, Nature 473 (2011) 174-180, http:// dx.doi.org/10.1038/nature10187.

[22] C. Le Maréchal, V. Peton, C. Plé, C. Vroland, J. Jardin, V. Briard-Bion, et al., Surface proteins of Propionibacterium freudenreichii are involved in its anti-inflammatory properties, J. Proteome 113 (2014) 447-461, http://dx.doi.org/10.1016/j.jprot. 2014.07.018.

[23] B. Sanchez, et al., Proteomics of stress response in Bifidobacterium, Front. Biosci. Volume 6905 (2008), http://dx.doi.org/10.2741/3198.

[24] B. Sánchez, L. Ruiz, M. Gueimonde, A. Margolles, Omics for the study of probiotic microorganisms, Food Res. Int. 54 (2013) 1061-1071, http://dx.doi.org/10.1016/j. foodres.2013.01.029.

[25] F. Turroni, F. Bottacini, E. Foroni, I. Mulder, J.-H. Kim, A. Zomer, et al., Genome analysis of Bifidobacterium bifidum PRL2010 reveals metabolic pathways for hostderived glycan foraging, Proc. Natl. Acad. Sci. U. S. A. 107 (2010) 19514-19519, http://dx.doi.org/10.1073/pnas.1011100107.

[26] E. Espino, K. Koskenniemi, L. Mato-Rodriguez, T.A. Nyman, J. Reunanen, J. Koponen, et al., Uncovering surface-exposed antigens of Lactobacillus rhamnosus by cell shaving proteomics and two-dimensional immunoblotting, J. Proteome Res. 14 (2015) 1010-1024, http://dx.doi.org/10.1021/pr501041a.

[27] M.-A. von Schillde, G. Hörmannsperger, M. Weiher, C.-A. Alpert, H. Hahne, C Bäuerl, et al., Lactocepin secreted by Lactobacillus exerts anti-inflammatory effects by selectively degrading proinflammatory chemokines, Cell Host Microbe 11 (2012) 387-396, http://dx.doi.org/10.1016/j.chom.2012.02.006.

[28] A. Gorg, G. Boguth, C. Obermaier, W. Weiss, Two-dimensional electrophoresis of proteins in an immobilized pH 4-12 gradient, Electrophoresis 19 (1998) 1516-1519, http://dx.doi.org/10.1002/elps.1150190850.

[29] L. Monteoliva, J.P. Albar, Differential proteomics: an overview of gel and non-ge based approaches, Brief. Funct. Genomic. Proteomic. 3 (2004) 220-239, http://dx. doi.org/10.1093/bfgp/3.3.220.

[30] C. Abdallah, E. Dumas-Gaudot, J. Renaut, K. Sergeant, Gel-based and gel-free quantitative proteomics approaches at a glance, Int. J. Plant Genomics. 1-17 (2012), http://dx.doi.org/10.1155/2012/494572.

[31] R.A. Siciliano, M.F. Mazzeo, Molecular mechanisms of probiotic action: a proteomic perspective, Curr. Opin. Microbiol. 15 (2012) 390-396, http://dx.doi.org/10.1016/j. mib.2012.03.006.

[32] J. Aires, M.-J. Butel, Proteomics, human gut microbiota and probiotics, Expert Rev. Proteomics. 8 (2011) 279-288, http://dx.doi.org/10.1586/epr.11.5.

[33] J.C. Tran, L. Zamdborg, D.R. Ahlf, J.E. Lee, A.D. Catherman, K.R. Durbin, et al., Mapping intact protein isoforms in discovery mode using top-down proteomics, $\mathrm{Na}$ ture 480 (2011) 254-258, http://dx.doi.org/10.1038/nature10575.

[34] P.H. O'Farrell, High resolution two-dimensional electrophoresis of proteins, J. Biol. Chem. 250 (1975) 4007-4021, http://dx.doi.org/10.1016/j.bbi.2008.05.010.

[35] K. Savijoki, A. Suokko, A. Palva, L. Valmu, N. Kalkkinen, P. Varmanen, Effect of heatshock and bile salts on protein synthesis of Bifidobacterium longum revealed by [35S]methionine labelling and two-dimensional gel electrophoresis, FEMS Microbiol. Lett. 248 (2005) 207-215, http://dx.doi.org/10.1016/j.femsle.2005.05.032.

[36] J.L. Lopez, Two-dimensional electrophoresis in proteome expression analysis, J. Chromatogr. B Anal. Technol. Biomed. Life Sci. 849 (2007) 190-202, http://dx doi.org/10.1016/j.jchromb.2006.11.049.

[37] T. Rabilloud, Membrane proteins and proteomics: love is possible, but so difficult Electrophoresis 30 (2009), http://dx.doi.org/10.1002/elps.200900050.

[38] C. Lamberti, E. Pessione, M.G. Giuffrida, R. Mazzoli, C. Barello, A. Conti, et al., Combined cup loading, bis(2-hydroxyethyl) disulfide, and protein precipitation protocols to improve the alkaline proteome of Lactobacillus hilgardii, Electrophoresis 28 (2007) 1633-1638, http://dx.doi.org/10.1002/elps.200600496.

[39] M. Unlü, M.E. Morgan, J.S. Minden, Difference gel electrophoresis: a single gel method for detecting changes in protein extracts, Electrophoresis 18 (1997) 2071-2077, http://dx.doi.org/10.1002/elps.1150181133.

[40] C. Alcántara, M. Zúñiga, Proteomic and transcriptomic analysis of the response to bile stress of Lactobacillus casei BL23, Microbiology 158 (2012) 1206-1218, http://dx.doi.org/10.1099/mic.0.055657-0.

[41] E. Hamon, P. Horvatovich, M. Bisch, F. Bringel, E. Marchioni, D. Aoudé-Werner et al., Investigation of biomarkers of bile tolerance in Lactobacillus casei using comparative proteomics, J. Proteome Res. 11 (2012) 109-118, http://dx.doi.org/10. 1021/pr200828t.

[42] L. Ruiz, B. Sánchez, C.G. de los Reyes-Gavilán, M. Gueimonde, A. Margolles, Coculture of Bifidobacterium longum and Bifidobacterium breve alters their protein expression profiles and enzymatic activities, Int. J. Food Microbiol. 133 (2009) 148-153, http://dx.doi.org/10.1016/j.jifoodmicro.2009.05.014.

[43] G.C. van Zanten, N. Sparding, A. Majumder, S.J. Lahtinen, B. Svensson, S. Jacobsen, The differential proteome of the probiotic Lactobacillus acidophilus NCFM grown on the potential prebiotic cellobiose shows upregulation of two $\beta$-glycoside hydrolases, Biomed Res. Int. 2015 (2015) 347216, http://dx.doi.org/10.1155/2015/ 347216.

[44] E. Izquierdo, P. Horvatovich, E. Marchioni, D. Aoude-Werner, Y. Sanz, S. Ennahar, 2$\mathrm{DE}$ and MS analysis of key proteins in the adhesion of Lactobacillus plantarum, a 
first step toward early selection of probiotics based on bacterial biomarkers, Electrophoresis 30 (2009) 949-956, http://dx.doi.org/10.1002/elps.200800399.

[45] J. Aires, P. Anglade, F. Baraige, M. Zagorec, M.-C. Champomier-Vergès, M.-J. Butel, Proteomic comparison of the cytosolic proteins of three Bifidobacterium longum human isolates and B. longum NCC2705, BMC Microbiol. 10 (2010) 29, http://dx doi.org/10.1186/1471-2180-10-29.

[46] C. Hidalgo-Cantabrana, B. Sánchez, D. Moine, B. Berger, C.G. de Los Reyes-Gavilán, M. Gueimonde, et al., Insights into the ropy phenotype of the exopolysaccharideproducing strain Bifidobacterium animalis subsp. lactis A1dOxR, Appl. Environ. Microbiol. 79 (2013) 3870-3874, http://dx.doi.org/10.1128/AEM.00633-13.

[47] B. Sánchez, M.-C. Champomier-Vergès, B. Stuer-Lauridsen, P. Ruas-Madiedo, P. Anglade, F. Baraige, et al., Adaptation and response of Bifidobacterium animalis subsp. lactis to bile: a proteomic and physiological approach, Appl. Environ. Microbiol. 73 (2007) 6757-6767, http://dx.doi.org/10.1128/AEM.00637-07.

[48] B. Sánchez, M.-C. Champomier-Vergès, M. del C. Collado, P. Anglade, F. Baraige, Y. Sanz, et al., Low-pH adaptation and the acid tolerance response of Bifidobacterium longum biotype longum, Appl. Environ. Microbiol. 73 (2007) 6450-6459, http://dx. doi.org/10.1128/AEM.00886-07.

[49] B. Sánchez, M.-C. Champomier-Vergès, P. Anglade, F. Baraige, C.G. de Los ReyesGavilán, A. Margolles, et al., Proteomic analysis of global changes in protein expression during bile salt exposure of Bifidobacterium longum NCIMB 8809, J. Bacteriol. 187 (2005) 5799-5808, http://dx.doi.org/10.1128/JB.187.16.5799-5808.2005.

[50] M. Miyagi, K.C.S. Rao, Proteolytic 180-labeling strategies for quantitative proteomics, Mass Spectrom. Rev. 26 (2007) 121-136, http://dx.doi.org/10.1002/mas.

[51] J.H. Ippel, L. Pouvreau, T. Kroef, H. Gruppen, G. Versteeg, P. Van Den Putten, et al., In vivo uniform $15 \mathrm{~N}$-isotope labelling of plants: using the greenhouse for structural proteomics, Proteomics 4 (2004) 226-234, http://dx.doi.org/10.1002/pmic. 200300506

[52] X. Chen, S. Wei, Y. Ji, X. Guo, F. Yang, Ouantitative Proteomics Using SILAC: Principles, Applications and Developments, 2015, http://dx.doi.org/10.1002/pmic. 201500108

[53] S.P. Gygi, B. Rist, S.A. Gerber, F. Turecek, M.H. Gelb, R. Aebersold, Quantitative analysis of complex protein mixtures using isotope-coded affinity tags, Nat. Biotechnol. 17 (1999) 994-999, http://dx.doi.org/10.1038/13690.

[54] K. Aggarwal, L.H. Choe, K.H. Lee, Shotgun proteomics using the iTRAQ isobaric tags, Brief. Funct. Genomic. Proteomic. 5 (2006) 112-120, http://dx.doi.org/10.1093/ bfgp/ell018.

[55] J. Parker, N. Zhu, M. Zhu, S. Chen, Profiling thiol redox proteome using isotope tag ging mass spectrometry, J. Vis. Exp. 2-7 (2012), http://dx.doi.org/10.3791/3766.

[56] V. Brun, C. Masselon, J. Garin, A. Dupuis, Isotope dilution strategies for absolute quantitative proteomics, J. Proteome 72 (2009) 740-749, http://dx.doi.org/10. 1016/j.jprot.2009.03.007.

[57] X. Fang, W.W. Zhang, Affinity separation and enrichment methods in proteomic analysis, J. Proteome 71 (2008) 284-303 doi: 10.1016/j.jprot.2008.06.011.

[58] J.M. Pratt, D.M. Simpson, M.K. Doherty, J. Rivers, S.J. Gaskell, R.J. Beynon, Multiplexed absolute quantification for proteomics using concatenated signature peptides encoded by QconCAT genes, Nat. Protoc. 1 (2006) 1029-1043, http:// dx.doi.org/10.1038/nprot.2006.129.

[59] J.R. Barr, V.L. Maggio, D.G. Patterson, G.R. Cooper, L.O. Henderson, W.E. Turner, et al., Isotope dilution-mass spectrometric quantification of specific proteins: model application with apolipoprotein A-I, Clin. Chem. 42 (1996) $1676-1682$.

[60] A. Iliuk, J. Galan, W.A. Tao, Playing tag with quantitative proteomics, Anal. Bioanal. Chem. 393 (2009) 503-513, http://dx.doi.org/10.1007/s00216-008-2386-0.

[61] T. Heunis, S. Deane, S. Smit, L.M.T. Dicks, Proteomic profiling of the acid stress response in Lactobacillus plantarum 423, J. Proteome Res. 13 (2014) 4028-4039, http://dx.doi.org/10.1021/pr500353x.

[62] M.A. A.O. Hussain, X. Wu, N. Natt, Cytosolic proteomes of Lactobacillus rhamnosus ATCC27773 cells grown in pH 5.5 and 6.5, J. Proteomics Comput. Biol. 2 (1) (2015) 7 http://www.avensonline.org/fulltextarticles/JPCB-02-0004.htm (accessed January 14, 2016).

[63] E. Guillaume, B. Berger, M. Affolter, M. Kussmann, Label-free quantitative proteomics of two Bifidobacterium longum strains, J. Proteome 72 (2009) 771-784 http://dx.doi.org/10.1016/j.jprot.2009.03.004.

[64] M. Meyrand, A. Guillot, M. Goin, S. Furlan, J. Armalyte, S. Kulakauskas, et al., Surface proteome analysis of a natural isolate of Lactococcus lactis reveals the presence of pili able to bind human intestinal epithelial cells, Mol. Cell. Proteomics 12 (2013) 3935-3947, http://dx.doi.org/10.1074/mcp.M113.029066.

[65] A. Pessione, C. Lamberti, L. Cocolin, S. Campolongo, A. Grunau, S. Giubergia, et al, Different protein expression profiles in cheese and clinical isolates of Enterococcus faecalis revealed by proteomic analysis, Proteomics 12 (2012) 431-447, http://dx. doi.org/10.1002/pmic.201100468.

[66] G. Klein, J.P. Schanstra, J. Hoffmann, H. Mischak, J. Siwy, K. Zimmermann, Proteomics as a quality control tool of pharmaceutical probiotic bacterial lysate products, PLoS ONE 8 (2013), e66682, http://dx.doi.org/10.1371/journal.pone.0066682.

[67] S. Wolff, A. Otto, D. Albrecht, J.S. Zeng, K. Büttner, M. Glückmann, et al., Gel-free and gel-based proteomics in Bacillus subtilis: a comparative study, Mol. Cell. Proteomics 5 (2006) 1183-1192, http://dx.doi.org/10.1074/mcp.M600069-MCP200.

[68] I.M. Carmen Piñeiro, Mónica Carrera, Benito Cañas, Xabier Lekube, Proteomics and Food Analysis: Principles, Techniques, and Applications, Handb. Food Anal. third ed., 2015 369-391. http://www.crcnetbase.com/doi/abs/10.1201/b18668-22 (accessed January 14, 2016).

[69] E. Mangiapane, R. Mazzoli, A. Pessione, B. Svensson, K. Riedel, E. Pessione, Ten years of subproteome investigations in lactic acid bacteria: a key for food starter and probiotic typing, J. Proteome 127 (2015) 332-339, http://dx.doi.org/10.1016/j.jprot. 2015.04.028.
[70] J. Koponen, K. Laakso, K. Koskenniemi, M. Kankainen, K. Savijoki, T.A. Nyman, et al., Effect of acid stress on protein expression and phosphorylation in Lactobacillus rhamnosus GG, J. Proteome 75 (2012) 1357-1374, http://dx.doi.org/10.1016/j. jprot.2011.11.009.

[71] Z. Zhai, F.P. Douillard, H. An, G. Wang, X. Guo, Y. Luo, et al., Proteomic characterization of the acid tolerance response in Lactobacillus delbrueckii subsp. bulgaricus CAUH1 and functional identification of a novel acid stress-related transcriptional regulator Ldb0677, Environ. Microbiol. 16 (2014) 1524-1537, http://dx.doi.org/ 10.1111/1462-2920.12280.

[72] K. Lee, H.G. Lee, K. Pi, Y.J. Choi, The effect of low pH on protein expression by the probiotic bacterium Lactobacillus reuteri, Proteomics 8 (2008) 1624-1630, http:// dx.doi.org/10.1002/pmic.200700663.

[73] C. Wu, G. He, J. Zhang, Physiological and proteomic analysis of Lactobacillus casei in response to acid adaptation, J. Ind. Microbiol. Biotechnol. 41 (2014) 1533-1540, http://dx.doi.org/10.1007/s10295-014-1487-3.

[74] A. Fernandez, J. Ogawa, S. Penaud, S. Boudebbouze, D. Ehrlich, M. van de Guchte, et al., Rerouting of pyruvate metabolism during acid adaptation in Lactobacillus bulgaricus, Proteomics 8 (2008) 3154-3163, http://dx.doi.org/10.1002/pmic. 200700974.

[75] J. Jin, Q. Qin, H. Guo, S. Liu, S. Ge, H. Zhang, et al., Effect of pre-stressing on the acidstress response in Bifidobacterium revealed using proteomic and physiological approaches, PLoS ONE 10 (2015), e0117702, http://dx.doi.org/10.1371/journal.pone. 0117702.

[76] L. Waddington, T. Cyr, M. Hefford, L.T. Hansen, M. Kalmokoff, Understanding the acid tolerance response of bifidobacteria, J. Appl. Microbiol. 108 (2010) 1408-1420, http://dx.doi.org/10.1111/j.1365-2672.2009.04540.x.

[77] P. Leverrier, J.P.C. Vissers, A. Rouault, P. Boyaval, G. Jan, Mass spectrometry proteomic analysis of stress adaptation reveals both common and distinct response pathways in Propionibacterium freudenreichii, Arch. Microbiol. 181 (2004) 215-230, http://dx.doi.org/10.1007/s00203-003-0646-0.

[78] Y. Cui, W. Liu, X. Qu, Z. Chen, X. Zhang, T. Liu, et al., A two component system is involved in acid adaptation of Lactobacillus delbrueckii subsp. bulgaricus, Microbiol. Res. 167 (2012) 253-261, http://dx.doi.org/10.1016/j.micres.2011.11.003.

[79] S. Siragusa, M. De Angelis, M. Calasso, D. Campanella, F. Minervini, R. Di Cagno, et al., Fermentation and proteome profiles of Lactobacillus plantarum strains during growth under food-like conditions, J. Proteome 96 (2014) 366-380, http://dx.doi. org/10.1016/j.jprot.2013.11.003.

[80] C.G. Bove, M. De Angelis, M. Gatti, M. Calasso, E. Neviani, M. Gobbetti, Metabolic and proteomic adaptation of Lactobacillus rhamnosus strains during growth under cheese-like environmental conditions compared to de Man, Rogosa, and Sharpe medium, Proteomics 12 (2012) 3206-3218, http://dx.doi.org/10.1002/ pmic.201200157.

[81] M. Dalmasso, J. Aubert, V. Briard-Bion, V. Chuat, S.-M. Deutsch, S. Even, et al., A temporal-omic study of Propionibacterium freudenreichii CIRM-BIA1 adaptation strategies in conditions mimicking cheese ripening in the cold, PLoS ONE 7 (2012), e29083, http://dx.doi.org/10.1371/journal.pone.0029083.

[82] K. Koskenniemi, J. Koponen, M. Kankainen, K. Savijoki, S. Tynkkynen, W.M. De Vos, et al., Proteome analysis of Lactobacillus rhamnosus GG using 2-D DIGE and mass spectrometry shows differential protein production in laboratory and industrialtype growth media, J. Proteome Res. 8 (2009) 4993-5007, http://dx.doi.org/10. $1021 /$ pr9003823.

[83] A. Hartke, S. Bouche, X. Gansel, P. Boutibonnes, Y. Auffray, Starvation-induced stress resistance in Lactococcus lactis subsp. lactis IL1403, Appl. Environ. Microbiol. 60 (1994) 3474.

[84] M.A. Hussain, M.I. Knight, M.L. Britz, Proteomic analysis of lactose-starved Lactobacillus casei during stationary growth phase, J. Appl. Microbiol. 106 (2009) 764-773, http://dx.doi.org/10.1111/j.1365-2672.2008.03961.x.

[85] A. Al-Naseri, J.P. Bowman, R. Wilson, R.E. Nilsson, M.L. Britz, Impact of lactose starvation on the physiology of Lactobacillus casei GCRL163 in the presence or absence of Tween 80, J. Proteome Res. 12 (2013) 5313-5322, http://dx.doi.org/10.1021/ pr400661g.

[86] M. Xiao, P. Xu, J. Zhao, Z. Wang, F. Zuo, J. Zhang, et al., Oxidative stress-related responses of Bifidobacterium longum subsp. longum BBMN68 at the proteomic level after exposure to oxygen, Microbiology 157 (2011) 1573-1588, http://dx.doi.org/ 10.1099/mic.0.044297-0.

[87] C. Li, P.-Z. Li, J.-W. Sun, G.-C. Huo, L.-B. Liu, Proteomic analysis of the response to $\mathrm{NaCl}$ stress of Lactobacillus bulgaricus, Biotechnol. Lett. 36 (2014) 2263-2269, http://dx.doi.org/10.1007/s10529-014-1601-7.

[88] P. Russo, M. de la Luz Mohedano, V. Capozzi, P.F. de Palencia, P. López, G. Spano, et al., Comparative proteomic analysis of Lactobacillus plantarum WCFS1 and $\Delta$ ctsR mutant strains under physiological and heat stress conditions, Int. J. Mol. Sci. 13 (2012) 10680-10696, http://dx.doi.org/10.3390/ijms130910680.

[89] R. Anastasiou, P. Leverrier, I. Krestas, A. Rouault, G. Kalantzopoulos, P. Boyaval, et al., Changes in protein synthesis during thermal adaptation of Propionibacterium freudenreichii subsp. shermanii, Int. J. Food Microbiol. 108 (2006) 301-314, http:// dx.doi.org/10.1016/j.ijfoodmicro.2005.11.015.

[90] S. Hörmann, C. Scheyhing, J. Behr, M. Pavlovic, M. Ehrmann, R.F. Vogel, Comparative proteome approach to characterize the high-pressure stress response of Lactobacillus sanfranciscensis DSM 20451(T), Proteomics 6 (2006) 1878-1885, http://dx. doi.org/10.1002/pmic.200402086.

[91] J. Zhao, P.C.K. Cheung, Comparative proteome analysis of Bifidobacterium longum subsp. infantis grown on Glucans from different sources and a model for their utilization, J. Agric. Food Chem. 61 (2013) 4360-4370, http://dx.doi.org/10.1021/ jf400792j.

92] O. Gilad, S. Jacobsen, B. Stuer-Lauridsen, M.B. Pedersen, C. Garrigues, B. Svensson, Combined transcriptome and proteome analysis of Bifidobacterium animalis 
subsp. lactis BB-12 grown on xylo-oligosaccharides and a model of their utilization, Appl. Environ. Microbiol. 76 (2010) 7285-7291, http://dx.doi.org/10.1128/AEM. 00738-10.

[93] O. Gilad, K. Hjernø, E.C. Østerlund, A. Margolles, B. Svensson, B. Stuer-Lauridsen, et al., Insights into physiological traits of Bifidobacterium animalis subsp. lactis BB-12 through membrane proteome analysis, J. Proteome 75 (2012) 1190-1200, http://dx.doi.org/10.1016/j.jprot.2011.10.031.

[94] A. Majumder, A. Sultan, R.R. Jersie-Christensen, M. Ejby, B.G. Schmidt, S.J. Lahtinen, et al., Proteome reference map of Lactobacillus acidophilus NCFM and quantitative proteomics towards understanding the prebiotic action of lactitol, Proteomics 11 (2011) 3470-3481, http://dx.doi.org/10.1002/pmic.201100115.

[95] M.F. Mazzeo, R. Lippolis, A. Sorrentino, S. Liberti, F. Fragnito, R.A. Siciliano, Lactobacillus acidophilus-rutin interplay investigated by proteomics, PLoS ONE 10 (2015), e0142376, http://dx.doi.org/10.1371/journal.pone.0142376.

[96] E. Hamon, P. Horvatovich, E. Izquierdo, F. Bringel, E. Marchioni, D. Aoudé-Werner, et al., Comparative proteomic analysis of Lactobacillus plantarum for the identification of key proteins in bile tolerance, BMC Microbiol. 11 (2011) 63, http://dx.doi. org/10.1186/1471-2180-11-63.

[97] J.Y. Lee, E.A.B. Pajarillo, M.J. Kim, J.P. Chae, D.K. Kang, Proteomic and transcriptional analysis of Lactobacillus johnsonii pf01 during bile salt exposure by itraq shotgun proteomics and quantitative RT-PCR, J. Proteome Res. 12 (2013) 432-443, http:// dx.doi.org/10.1021/pr300794y.

[98] L. Ruiz, Y. Couté, B. Sánchez, C.G. De los Reyes-Gavilán, J.C. Sanchez, A. Margolles, The cell-envelope proteome of Bifidobacterium longum in an in vitro bile environment, Microbiology 155 (2009) 957-967, http://dx.doi.org/10.1099/mic.0. 024273-0.

[99] H. An, F.P. Douillard, G. Wang, Z. Zhai, J. Yang, S. Song et al., Integrated transcriptomic and proteomic analysis of the bile stress response in a centenarian-originated probiotic Bifidobacterium longum BBMN68., Mol. Cell. Proteomics. (2014) 2558-2572. doi:http://dx.doi.org/10.1074/mcp.M114.039156.

[100] R. Wu, Z. Sun, J. Wu, H. Meng, H. Zhang, Effect of bile salts stress on protein synthesis of Lactobacillus casei Zhang revealed by 2-dimensional gel electrophoresis, J. Dairy Sci. 93 (2010) 3858-3868, http://dx.doi.org/10.3168/jds.2009-2967.

[101] P. Burns, B. Sánchez, G. Vinderola, P. Ruas-Madiedo, L. Ruiz, A. Margolles, et al., Inside the adaptation process of Lactobacillus delbrueckii subsp. lactis to bile, Int. J. Food Microbiol. 142 (2010) 132-141, http://dx.doi.org/10.1016/j.ijfoodmicro. 2010.06.013.

[102] K. Koskenniemi, K. Laakso, J. Koponen, M. Kankainen, D. Greco, P. Auvinen, et al., Proteomics and transcriptomics characterization of bile stress response in probiotic Lactobacillus rhamnosus GG, Mol. Cell. Proteomics 10 (2011), M110.002741, http://dx.doi.org/10.1074/mcp.M110.002741.

[103] J. Yuan, B. Wang, Z. Sun, X. Bo, X. Yuan, X. He, et al., Analysis of host-inducing proteome changes in Bifidobacterium longum NCC2705 grown in vivo, J. Proteome Res. 7 (2008) 375-385, http://dx.doi.org/10.1021/pr0704940.

[104] J.-H. Kim, H.J. An, D. Garrido, J.B. German, C.B. Lebrilla, D.A. Mills, Proteomic analysis of Bifidobacterium longum subsp. infantis reveals the metabolic insight on consumption of prebiotics and host glycans, PLoS One 8 (2013), e57535, http://dx. doi.org/10.1371/journal.pone.0057535.

[105] M. van de Guchte, T. Chaze, G. Jan, M.Y. Mistou, Properties of probiotic bacteria explored by proteomic approaches, Curr. Opin. Microbiol. 15 (2012) 381-389, http:// dx.doi.org/10.1016/j.mib.2012.04.003.

[106] M. Olivares, M. Laparra, Y. Sanz, Oral administration of Bifidobacterium longum CECT 7347 modulates jejunal proteome in an in vivo gliadin-induced enteropathy animal model, J. Proteome 77 (2012) 310-320, http://dx.doi.org/10.1016/j.jprot. 2012.09.005.

[107] Y. Kim, J.Y. Whang, K.Y. Whang, S. Oh, S.H. Kim, Characterization of the cholesterolreducing activity in a cell-free supernatant of Lactobacillus acidophilus ATCC 43121, Biosci. Biotechnol. Biochem. 72 (2008) 1483-1490, http://dx.doi.org/10.1271/bbb. 70802.

[108] J. Lee, Y. Kim, H.S. Yun, J.G. Kim, S. Oh, S.H. Kim, Genetic and proteomic analysis of factors affecting serum cholesterol reduction by Lactobacillus acidophilus A4, Appl. Environ. Microbiol. 76 (2010) 4829-4835, http://dx.doi.org/10.1128/AEM.0289209.

[109] Y.F. Chen, W.J. Zhao, R.N. Wu, Z.H. Sun, W.Y. Zhang, J.C. Wang, et al., Proteome analysis of Lactobacillus helveticus H9 during growth in skim milk, J. Dairy Sci. 97 (2014) 7413-7425, http://dx.doi.org/10.3168/jds.2014-8520.

[110] B. Lee, S. Tachon, R.A. Eigenheer, B.S. Phinney, M.L. Marco, Lactobacillus casei lowtemperature, dairy-associated proteome promotes persistence in the mammalian digestive tract, J. Proteome Res. 14 (2015) 3136-3147, http://dx.doi.org/10.1021/ acs.jproteome.5b00387.

[111] M. Calasso, R. Di Cagno, M. De Angelis, D. Campanella, F. Minervini, M. Gobbetti, Effects of the peptide pheromone plantaricin A and cocultivation with Lactobacillus sanfranciscensis DPPMA174 on the exoproteome and the adhesion capacity of Lactobacillus plantarum DC400, Appl. Environ. Microbiol. 79 (2013) 2657-2669, http://dx.doi.org/10.1128/AEM.03625-12.

[112] B. Sánchez, I. González-Rodríguez, S. Arboleya, P. López, A. Suárez, P. RuasMadiedo, et al., The effects of Bifidobacterium breve on immune mediators and proteome of HT29 cells monolayers, Biomed Res. Int. 2015 (2015) 479140, http://dx. doi.org/10.1155/2015/479140.

[113] X. Wang, F. Yang, C. Liu, H. Zhou, G. Wu, S. Qiao, et al., Dietary supplementation with the probiotic Lactobacillus fermentum 15007 and the antibiotic aureomycin differentially affects the small intestinal proteomes of weanling piglets, J. Nutr. 142 (2012) 7-13, http://dx.doi.org/10.3945/jn.111.147074.

[114] C.A. Kolmeder, W.M. de Vos, Metaproteomics of our microbiome - developing insight in function and activity in man and model systems, J. Proteome 97 (2014) 3-16, http://dx.doi.org/10.1016/j.jprot.2013.05.018.
[115] A. Siggins, E. Gunnigle, F. Abram, Exploring mixed microbial community functioning: recent advances in metaproteomics, FEMS Microbiol. Ecol. 80 (2012) 265-280, http://dx.doi.org/10.1111/j.1574-6941.2011.01284.x.

[116] P.E. Abraham, R.J. Giannone, W. Xiong, R.L. Hettich, Metaproteomics: extracting and mining proteome information to characterize metabolic activities in microbia communities, Curr. Protoc. Bioinformatics. 46 (2014) 13.26.1-13.26.14, http://dx. doi.org/10.1002/0471250953.bi1326s46.

[117] K. Chourey, J. Jansson, N. Verberkmoes, M. Shah, K.L. Chavarria, L.M. Tom, et al., Direct cellular lysis/protein extraction protocol for soil metaproteomics, J. Proteome Res. 9 (2010) 6615-6622, http://dx.doi.org/10.1021/pr100787q.

[118] A. Hevia, S. Delgado, A. Margolles, B. Sánchez, sApplication of density gradient for the isolation of the fecal microbial stool component and the potential use thereof, Sci. Rep. 5 (2015) 16807, http://dx.doi.org/10.1038/srep16807.

[119] E.S. Klaassens, W.M. De Vos, E.E. Vaughan, Metaproteomics approach to study the functionality of the microbiota in the human infant gastrointestinal tract, Appl. Environ. Microbiol. 73 (2007) 1388-1392, http://dx.doi.org/10.1128/AEM.01921-06.

[120] N.C. Verberkmoes, A.L. Russell, M. Shah, A. Godzik, M. Rosenquist, J. Halfvarson, et al., Shotgun metaproteomics of the human distal gut microbiota, ISME J. 3 (2009) 179-189, http://dx.doi.org/10.1038/ismej.2008.108.

[121] T. Muth, C.A. Kolmeder, J. Salojärvi, S. Keskitalo, M. Varjosalo, F.J. Verdam, et al. Navigating through metaproteomics data - a logbook of database searching, Proteomics n/a-n/a (2015), http://dx.doi.org/10.1002/pmic.201400560.

[122] C.A. Kolmeder, M. de Been, J. Nikkilä, I. Ritamo, J. Mättö, L. Valmu, et al., Comparative metaproteomics and diversity analysis of human intestinal microbiota testifies for its temporal stability and expression of core functions, PLoS One 7 (2012), http://dx.doi.org/10.1371/journal.pone.0029913.

[123] K. Rooijers, C. Kolmeder, C. Juste, J. Doré, M. de Been, S. Boeren, et al., An iterative workflow for mining the human intestinal metaproteome, BMC Genomics 12 (2011) 6, http://dx.doi.org/10.1186/1471-2164-12-6.

[124] M. Ferrer, V.A.P.M. dos Santos, S.J. Ott, A. Moya, Gut microbiota disturbance during antibiotic therapy: a multi-omic approach, Gut Microbes 5 (2013) 1591-1601, http://dx.doi.org/10.1136/gutjnl-2012-303184.

[125] C.A. Kolmeder, J. Ritari, F.J. Verdam, T. Muth, S. Keskitalo, M. Varjosalo, et al., Colonic metaproteomic signatures of active bacteria and the host in obesity, Proteomics 15 (2015) 3544-3552, http://dx.doi.org/10.1002/pmic.201500049.

[126] J.S. Lichtman, J.L. Sonnenburg, J.E. Elias, Monitoring host responses to the gut microbiota, ISME J. (2015) 1-8, http://dx.doi.org/10.1038/ismej.2015.93.

[127] L. Ruiz, B. Sánchez, P. Ruas-Madiedo, C.G. de Los Reyes-Gavilán, A. Margolles, Cell envelope changes in Bifidobacterium animalis ssp. lactis as a response to bile, FEMS Microbiol. Lett. 274 (2007) 316-322, http://dx.doi.org/10.1111/j.15746968.2007.00854.x.

[128] B. Sánchez, P. Bressollier, M.C. Urdaci, Exported proteins in probiotic bacteria: adhesion to intestinal surfaces, host immunomodulation and molecular crosstalking with the host, FEMS Immunol. Med. Microbiol. 54 (2008) 1-17, http://dx doi.org/10.1111/j.1574-695X.2008.00454.x.

[129] A. Pessione, G. Lo Bianco, E. Mangiapane, S. Cirrincione, E. Pessione, Characterization of potentially probiotic lactic acid bacteria isolated from olives: evaluation of short chain fatty acids production and analysis of the extracellular proteome Food Res. Int. 67 (2015) 247-254, http://dx.doi.org/10.1016/j.foodres.2014.11.029.

[130] I. González-Rodríguez, L. Ruiz, M. Gueimonde, A. Margolles, B. Sánchez, Factors involved in the colonization and survival of bifidobacteria in the gastrointestinal tract, FEMS Microbiol. Lett. 340 (2013) 1-10, http://dx.doi.org/10.1111/1574 6968.12056

[131] D.M. Remus, R.S. Bongers, M. Meijerink, F. Fusetti, B. Poolman, P. de Vos, et al., Impact of Lactobacillus plantarum sortase on target protein sorting, gastrointestinal persistence, and host immune response modulation, J. Bacteriol. 195 (2013) 502-509, http://dx.doi.org/10.1128/JB.01321-12.

[132] E.K. Call, Y.J. Goh, K. Selle, T.R. Klaenhammer, S. O'Flaherty, Sortase-deficient lactobacilli: effect on immunomodulation and gut retention, Microbiology 161 (2015) 311-321, http://dx.doi.org/10.1099/mic.0.000007.

[133] X. Wei, X. Yan, X. Chen, Z. Yang, H. Li, D. Zou, et al., Proteomic analysis of the interaction of Bifidobacterium longum NCC2705 with the intestine cells Caco- 2 and identification of plasminogen receptors, J. Proteome 108 (2014) 89-98, http://dx.doi. org/10.1016/j.jprot.2014.04.038.

[134] J. Antikainen, V. Kuparinen, V. Kupannen, K. Lähteenmäki, T.K. Korhonen, pHdependent association of enolase and glyceraldehyde-3-phosphate dehydrogenase of Lactobacillus crispatus with the cell wall and lipoteichoic acids, J. Bacteriol. 189 (2007) 4539-4543, http://dx.doi.org/10.1128/JB.00378-07.

[135] R. Kuwana, N. Yamamoto, Increases in GroES and GroEL from Lactobacillus acidophilus L-92 in response to a decrease in medium $\mathrm{pH}$, and changes in cytokine release from splenocytes: transcriptome and proteome analyses, J. Biosci. Bioeng. 114 (2012) 9-16, http://dx.doi.org/10.1016/j.jbiosc.2012.02.010.

[136] M. Candela, M. Centanni, J. Fiori, E. Biagi, S. Turroni, C. Orrico, et al., DnaK from Bifidobacterium animalis subsp. lactis is a surface-exposed human plasminogen receptor upregulated in response to bile salts, Microbiology 156 (2010) 1609-1618 doi:10.1099/mic.0.038307-0.

[137] B. Sánchez, M.C. Urdaci, A. Margolles, Extracellular proteins secreted by probiotic bacteria as mediators of effects that promote mucosa-bacteria interactions, Microbiology 156 (2010) 3232-3242, http://dx.doi.org/10.1099/mic.0.044057-0.

[138] B. Sánchez, N.N. Saad, J.M.J.-M.J.-M.M. Schmitter, P. Bressollier, M.C.M.C. Urdaci, B. Sanchez, et al., Adhesive properties, extracellular protein production, and metabolism in the Lactobacillus rhamnosus GG strain when grown in the presence of mucin, J. Microbiol. Biotechnol. 20 (2010) 978-984, http://dx.doi.org/10.4014/ jmb.0911.11007.

[139] B. Sanchez, L. Ruiz, A. Suarez, C.G. de los Reyes-Gavilan, A. Margolles, Human cecum content modulates production of extracellular proteins by food and 
probiotic bacteria, FEMS Microbiol. Lett. 324 (2011) 189-194, http://dx.doi.org/10. 1111/j.1574-6968.2011.02408.x.

[140] S. Guglielmetti, I. Tamagnini, D. Mora, M. Minuzzo, A. Scarafoni, S. Arioli, et al., Implication of an outer surface lipoprotein in adhesion of Bifidobacterium bifidum to Caco-2 cells, Appl. Environ. Microbiol. 74 (2008) 4695-4702, http://dx.doi.org/ 10.1128/AEM.00124-08.

[141] F. Turroni, F. Serafini, M. Mangifesta, S. Arioli, D. Mora, D. van Sinderen, et al., Expression of sortase-dependent pili of Bifidobacterium bifidum PRL2010 in response to environmental gut conditions, FEMS Microbiol. Lett. 357 (2014) 23-33, http:// dx.doi.org/10.1111/1574-6968.12509.

[142] P. Tripathi, A. Beaussart, D. Alsteens, V. Dupres, I. Claes, I. Von Ossowski, et al., Adhesion and nanomechanics of pili from the probiotic Lactobacillus rhamnosus GG, ACS Nano 7 (2013) 3685-3697, http://dx.doi.org/10.1021/nn400705u.

[143] N. Ashida, S. Yanagihara, T. Shinoda, N. Yamamoto, Characterization of adhesive molecule with affinity to Caco-2 cells in Lactobacillus acidophilus by proteome analysis, J. Biosci. Bioeng. 112 (2011) 333-337, http://dx.doi.org/10.1016/j.jbiosc.2011. 06.001.

[144] J. Rintahaka, X. Yu, R. Kant, A. Palva, I. von Ossowski, Phenotypical analysis of the Lactobacillus rhamnosus GG fimbrial spaFED operon: surface expression and functional characterization of recombinant SpaFED pili in Lactococcus lactis, PLoS ONE 9 (2014), e113922, http://dx.doi.org/10.1371/journal.pone.0113922.

[145] V. Vastano, A. Pagano, A. Fusco, G. Merola, M. Sacco, G. Donnarumma, The Lactobacillus plantarum Eno A1 enolase is involved in immunostimulation of Caco- 2 cells and in biofilm development, Adv. Exp. Med. Biol. (2015), http://dx.doi.org/10. 1007/5584_2015_5009.

[146] C. Castaldo, V. Vastano, R.A. Siciliano, M. Candela, M. Vici, L. Muscariello, et al., Surface displaced alfa-enolase of Lactobacillus plantarum is a fibronectin binding protein, Microb. Cell Factories 8 (2009) 14, http://dx.doi.org/10.1186/1475-2859-814.

[147] Human Microbiome Project Consortium, A framework for human microbiome research, Nature 486 (2012) 215-221, http://dx.doi.org/10.1038/nature11209.

[148] J. Qin, Y. Li, Z. Cai, S. Li, J. Zhu, F. Zhang, et al., A metagenome-wide association study of gut microbiota in type 2 diabetes, Nature 490 (2012) 55-60, http://dx.doi.org 10.1038/nature 11450

[149] Human Microbiome Project Consortium, Structure, function and diversity of the healthy human microbiome, Nature 486 (2012) 207-214, http://dx.doi.org/10. 1038/nature 11234.

[150] R.D. Finn, P. Coggill, R.Y. Eberhardt, S.R. Eddy, J. Mistry, A.L. Mitchell, et al., The Pfam protein families database: towards a more sustainable future, Nucleic Acids Res. 44 (2016) D279-D285, http://dx.doi.org/10.1093/nar/gkv1344.

[151] A. Wilke, J. Bischof, W. Gerlach, E. Glass, T. Harrison, K.P. Keegan, et al., The MGRAST metagenomics database and portal in 2015, Nucleic Acids Res. 44 (2016) D590-D594, http://dx.doi.org/10.1093/nar/gkv1322.

[152] V.M. Markowitz, I.-M.A. Chen, K. Chu, E. Szeto, K. Palaniappan, M. Pillay, et al., IMG/ M 4 version of the integrated metagenome comparative analysis system, Nucleic Acids Res. 42 (2014) D568-D573, http://dx.doi.org/10.1093/nar/gkt919.

[153] R.L. Tatusov, N.D. Fedorova, J.D. Jackson, A.R. Jacobs, B. Kiryutin, E.V. Koonin, et al., The COG database: an updated version includes eukaryotes, BMC Bioinformatics 4 (2003) 41, http://dx.doi.org/10.1186/1471-2105-4-41.

[154] M. Kanehisa, S. Goto, Y. Sato, M. Kawashima, M. Furumichi, M. Tanabe, Data, information, knowledge and principle: back to metabolism in KEGG, Nucleic Acids Res. 42 (2014), http://dx.doi.org/10.1093/nar/gkt1076.

[155] O. Manor, R. Levy, E. Borenstein, Mapping the inner workings of the microbiome: genomic- and metagenomic-based study of metabolism and metabolic interactions in the human microbiome, Cell Metab. 20 (2014) 742-752, http://dx.doi. org/10.1016/j.cmet.2014.07.021.

[156] R. Joice, K. Yasuda, A. Shafquat, X.C. Morgan, C. Huttenhower, Determining microbial products and identifying molecular targets in the human microbiome, Cell Metab. 20 (2014) 731-741, http://dx.doi.org/10.1016/j.cmet.2014.10.003.
[157] Y. Ye, J.-H. Choi, H. Tang, RAPSearch: a fast protein similarity search tool for short reads, BMC Bioinformatics. 12 (2011) 159, http://dx.doi.org/10.1186/1471-210512-159.

[158] D.H. Huson, C. Xie, A poor man's BLASTX-high-throughput metagenomic protein database search using PAUDA, Bioinformatics 30 (2014) 38-39, http://dx.doi.org/ 10.1093/bioinformatics/btt254.

[159] P. Dudhagara, S. Bhavsar, C. Bhagat, A. Ghelani, R. Patel, S. Bhavsar, et al., Web resources for metagenomics studies, Genomics. Proteomics Bioinformatics. 13 (2015) 296-303, http://dx.doi.org/10.1016/j.gpb.2015.10.003.

[160] Y. Kim, I. Koh, M. Rho, Deciphering the human microbiome using next-generation sequencing data and bioinformatics approaches, Methods 79-80 (2015) 52-59, http://dx.doi.org/10.1016/j.ymeth.2014.10.022.

[161] B. Mesuere, G. Debyser, M. Aerts, B. Devreese, P. Vandamme, P. Dawyndt, The unipept metaproteomics analysis pipeline, Proteomics 15 (2015) 1437-1442, http://dx.doi.org/10.1002/pmic.201400361.

[162] T. Muth, A. Behne, R. Heyer, F. Kohrs, D. Benndorf, M. Hoffmann, et al., The MetaProteomeAnalyzer: a powerful open-source software suite for metaproteomics data analysis and interpretation, J. Proteome Res. 14 (2015) 1557-1565, http://dx.doi.org/10.1021/pr501246w.

[163] A. Tholey, C. Treitz, M. Kussmann, E. Bendixen, S.P. Schrimpf, M.O. Hengartner, Model organisms proteomics-from holobionts to human nutrition, Proteomics 13 (2013) 2537-2541, http://dx.doi.org/10.1002/pmic.201370144.

[164] W.-L. Wang, S.-Y. Xu, Z.-G. Ren, L. Tao, J.-W. Jiang, S.-S. Zheng, Application of metagenomics in the human gut microbiome, World J. Gastroenterol. 21 (2015) 803-814, http://dx.doi.org/10.3748/wjg.v21.i3.803.

[165] E. Qeli, C.H. Ahrens, PeptideClassifier for protein inference and targeted quantitative proteomics, Nat. Biotechnol. 28 (2010) 647-650, http://dx.doi.org/10.1038/ nbt0710-647.

[166] Y.F. Li, R.J. Arnold, Y. Li, P. Radivojac, O. Sheng, H. Tang, A Bayesian approach to protein inference problem in shotgun proteomics, Lect. Notes Comput. Sci. (Including Subser. Lect. Notes Artif. Intell. Lect. Notes Bioinformatics) 2008, pp. 167-180, http://dx.doi.org/10.1007/978-3-540-78839-3_15.

[167] T. Huang, H. Gong, C. Yang, Z. He, ProteinLasso: a Lasso regression approach to protein inference problem in shotgun proteomics, Comput. Biol. Chem. 43 (2013) 46-54, http://dx.doi.org/10.1016/j.compbiolchem.2012.12.008.

[168] W. Xiong P.E. Abraham, Z. Li, C. Pan, R.L. Hettich, Microbial metaproteomics for characterizing the range of metabolic functions and activities of human gut microbiota, Proteomics 15 (2015) 3424-3438, http://dx.doi.org/10.1002/pmic. 201400571.

[169] S. Shoaie, J. Nielsen, Elucidating the interactions between the human gut microbiota and its host through metabolic modeling, Front. Genet. 5 (2014) 86, http://dx. doi.org/10.3389/fgene.2014.00086.

[170] B. Ji, J. Nielsen, From next-generation sequencing to systematic modeling of the gut microbiome, Front. Genet. 6 (2015) 219, http://dx.doi.org/10.3389/fgene.2015. 00219 .

[171] I.E. El-Semman, F.H. Karlsson, S. Shoaie, I. Nookaew, T.H. Soliman, J. Nielsen, Genome-scale metabolic reconstructions of Bifidobacterium adolescentis L2-32 and Faecalibacterium prausnitzii A2-165 and their interaction, BMC Syst. Biol. 8 (2014) 41, http://dx.doi.org/10.1186/1752-0509-8-41.

[172] M. Shafiei, K.A. Dunn, H. Chipman, H. Gu, J.P. Bielawski, BiomeNet: a Bayesian model for inference of metabolic divergence among microbial communities, PLoS Comput. Biol. 10 (2014), e1003918, http://dx.doi.org/10.1371/journal.pcbi. 1003918.

[173] G. Leoni, A. Rosato, G. Perozzi, C. Murgia, Zinc proteome interaction network as a model to identify nutrient-affected pathways in human pathologies, Genes Nutr. 9 (2014) 436, http://dx.doi.org/10.1007/s12263-014-0436-0. 